GEOLOGICAL SURVEY CIRCULAR 564

\title{
Occurrences of Gold and \\ Other Metals in the Upper Chulitna District, Alaska
}

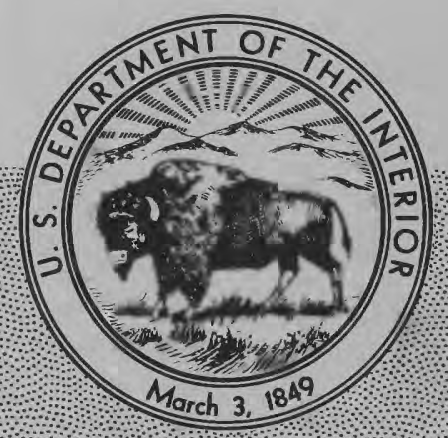





\title{
Occurrences of Gold and Other Metals in the Upper Chulitna District, Alaska
}

\author{
By C. C. Hawley and Allen L. Clark
}

GEOLOGICAL SURVEY CIRCULAR 564 
United States Department of the Interior STEWART L. UDALL, Secretary

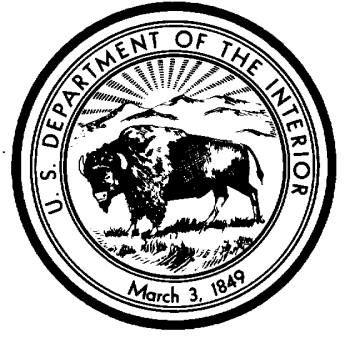

Geological Survey

William T. Pecora, Director

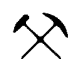




\section{CONTENTS}

\section{Page}

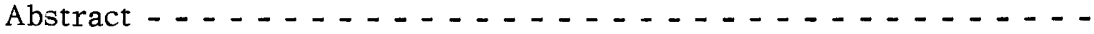

Introduction _. . . . . . . . . . . . . . . . .

Acknowledgments . . . . . . . . . . . . . . . .

Colorado Creek area- . . . . . . . . . . . . . . . . . .

Golden Zone area _ . . . . . . . . . . . . . . . . . .

Breccia pipe and mineralized rock _ . . . . . . . . . . -

Economic significance of the deposit _. . . . . . . . . .

Blind Creek area- . . . . . . . . . . . . . . . . . . .

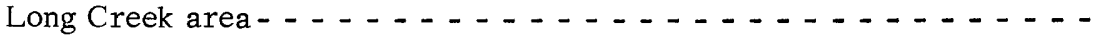

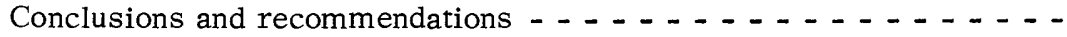

Stream-sediment samples _ . . . . . . . . . . . . . . .

Districtwide summary and recommendations . . . . . . . . . . .

References . . . . . . . . . . . . . . . . . . . . .

\section{ILLUSTRATIONS}

Figure 1. Index map showing location of the upper Chulitna district - - Page

2. Map showing the location of four mineralized areas in the upper Chulitna district _. . . . . . . . . . . . -

3. Generalized geologic map of the Colorado Creek area - . - -

4. Generalized geologic map of the Golden Zone mine area - - -

5. Sections of the Golden Zone porphyry stock and breccia pipe . . . . . . . . . . . . . . . . . . .

6. Generalized geologic map showing assay data, Golden Zone mine . . . . . . . . . . . . . . . . . . . .

7. Map showing distribution of mineralized rock, Golden Zone mine - . . . . . . . . . . . . . . . . . .

8. Generalized geologic map of the Blind Creek area - - . - -

9. Generalized geologic map of the Long Creek area - - - - -

10. Map showing location and gold concentration of streamsediment samples, upper Chulitna district _ . . . . . . -

\section{TABLES}

Table 1. Analyses of samples from the Colorado Creek area - - - - -

2. Analyses of samples from the Golden Zone, Blind Creek, and Long Creek areas . . . . . . . . . . . . . . .

3. Analyses of stream-sediment samples, upper Chulitna district . . . . . . . . . . . . . . . . . 


\title{
Occurrences of Gold and Other Metals in the Upper Chulitna District, Alaska
}

\author{
By C. C. Hawley and Allen L. Clark
}

\begin{abstract}
Gold and other metals form deposits clustered in three parts of the upper Chulitna district, near Colorado Creek, the Golden Zone in Bryn Mawr Creek, and Long Creek. Trace amounts of gold in thick quartz veins are in the major Blind Creek fault zone, and scattered small vein deposits and anomalous amounts of gold and other metals in stream sediments indicate widespread mineralization in the district.

The mineral occurrences at Colorado Creek and the Golden Zone are associated with small quartz dioriteporphyry stocks; they are of vein, disseminated, and breccia-pipe types. Gold accounts for most of their value, but the deposits are complex and contain abundant arsenic and locally abundant antimony, copper, silver, and zinc, and some molybdenum, tin, cadmium, and bismuth. The deposits at Long Creek are apparently clustered around small quartz porphyry plugs. They contain copper, subordinate amounts of gold and silver, and trace amounts of tin and molybdenum.
\end{abstract}

\section{INTRODUCTION}

Gold and other metals occur in brecciapipes, veins, and disseminated deposits at several places in the upper Chulitna district, on the southern flank of the Alaska Range. The main purpose of this report, made as part of the U.S. Geological Survey's Heavy Metals program, is to call attention to four areas that contain deposits of gold or other metals. From north to south these are: Colorado Creek, Golden Zone, Blind Creek, and Long Creek. The main economic features of each area are:

Colorado Creek area.-A stock of biotite quartz diorite porphyry about 1,500 feet wide by 2,000 feet long has associated arsenic-gold-antimony deposits which contain minor amounts of copper, bismuth, and tin. One sulfide-rich body appears to be a breccia pipe similar to that of the Golden Zone.

Golden Zone area. - The main mineralization at the Old Golden Zone mine is in a breccia-pipe deposit that is 200 to 300 feet across and probably extends in depth to more than 1,000 feet. Although the grade of the deposit is uncertain, it is estimated to contain more than $\$ 10,000,000$ worth of m etals, principally gold, silver, and copper, but with anomalous amounts of tin, molybdenum, bismuth, c admium, and boron.

Blind Creek.-A major fault zone at Blind Creek contains quartz-rich breccia filling as much as 200 feet thick which contains a trace of gold, arsenic, lead, and zinc.
Long Creek.-Gold- and silver-bearing copper occurrences are widely distributed near Long Creek. The main copper concentration is at the old Copper King prospect, but very sparse amounts of chalcopyrite, molybdenite, and pyrite occur in quartz porphyry plugs nearby. An area of strongly hornfelsed rocks, centered around the main quartz porphyry plugs, possibly is underlain by a quartz porphyry stock at shallow depth.

Results of stream-sediment sampling in the district are shown in figure 10 and table 3.

The upper Chulitna district, southeast of Mount McKinley National Park (fig. 1), is only 8 to 10 miles from the Alaska Railroad, but at present is best reached by small fixed-wing aircraft or helicopter, because roads into the district from the railroadhave been abandoned.

\section{Acknowledgments}

We gratefully acknowledge the aid and encouragement received from J. J. Mulligan and J. H. Herdlick, U.S. Bureau of Mines. Because the only underground mine workings of the area, those of the Golden Zone mine, are now inaccessible, much assay data is taken from maps contained in a report by Mulligan, Warfield, and Wells (1967) or from unpublished maps furnished by H. R. Beckwith, General Manager of Cemco, Inc., or $\mathrm{C}$. H. Herbert.

We would also like to acknowledge the help of Jon Alan Benfer, who served as field assistant, and of Cliff Hudson, bush pilot of Talkeetna, Alaska, who furnished skilled transport to and from the area.

\section{COLORADO CREEK AREA}

Arsenic-gold-antimony deposits in the Colorado Creek area (fig. 2) are associated with a small stock of hornblende-biotite quartz diorite porphyry. The stock is bisected by the deep canyon of Colorado Creek. The stock itself is almost inaccessible except at the bottom of the canyon (approximately 200 feet deep), but it appears generally bleached and locally contains disseminated chalcopyrite (as at the locality noted, fig. 3). The northern and southern contacts of the stock, as exposed in the canyon, are both iron stained, and the southern contact is marked by a zone of tactite, approximately 2 feet wide, containing 


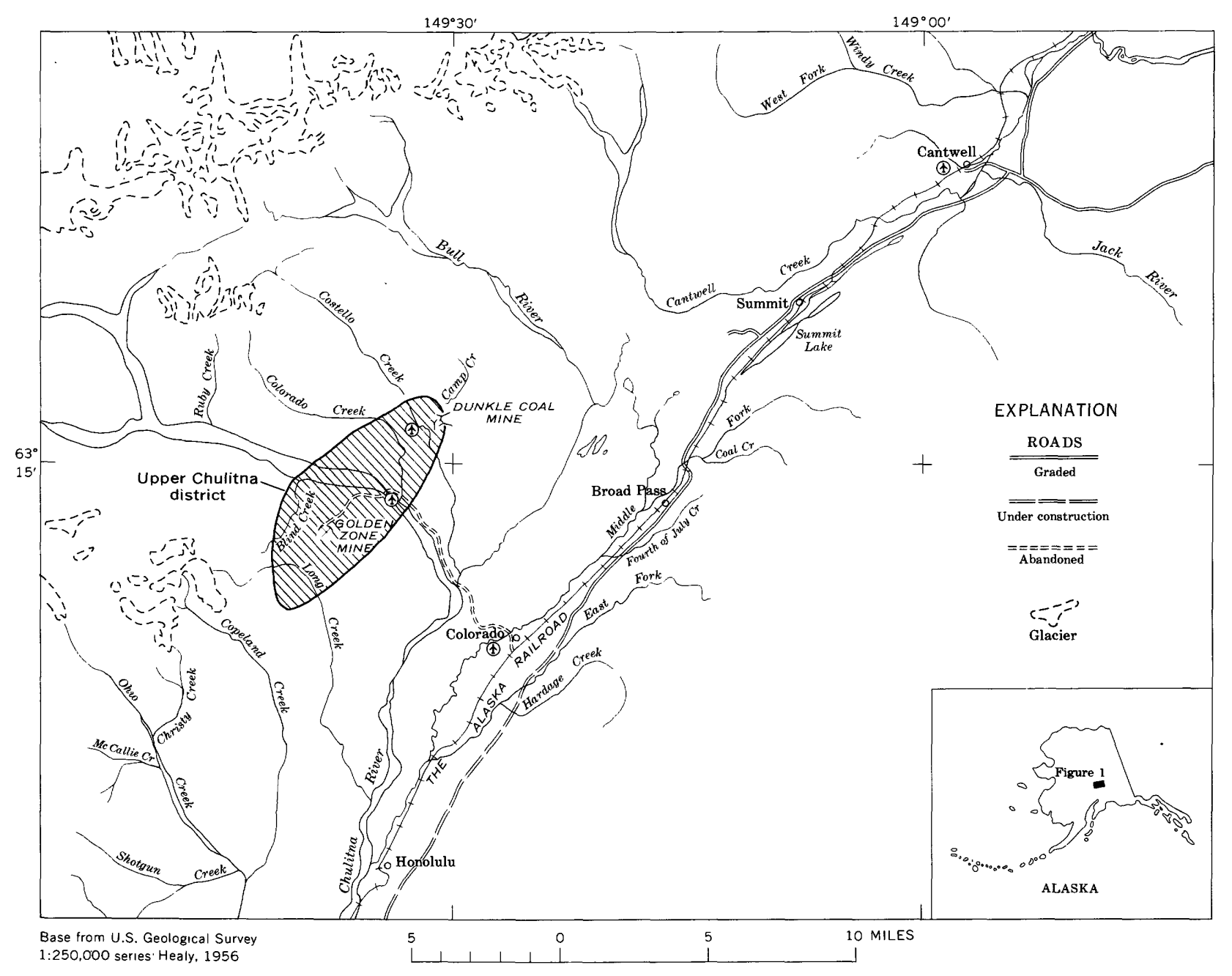

Figure 1.-Location of the upper Chulitna district.

abundant garnet, actinolite, and epidote. The surrounding rocks are hornfelsed and locally are strongly sulfidized.

The main sulfide occurrences are (1) at a previously unprospected knob about 750 feet west-southwest of the Silver King prospect, and (2) at the Silver King prospect itself. The Silver King prospect pits are about 6,000 feet north of the location shown on the Healy A-6 quadrangle map (scale, 1:63,360). Another occurrence is about 750 feet southwest of the main Silver King prospect pits, where an arsenopyritestibnite-quartz lode as much as 10 feet wide crops out in Colorado Creek. The new occurrence (locality 1) is a highly sulfidized mass of altered porphyry and hornfels at least 50 feet across that strongly resembles the highly broken and sulfidized rock of the Golden Zone pipe. Arsenopyrite is very abundant, but some chalcopyrite is present, and spectrographic analyses of samples show highly anomalous amounts of bismuth, cobalt, and tin in some samples (table 1). The gold content of samples (table 1) was generally less than $10 \mathrm{ppm}$ (parts per million), but one sample
(1A) showed 170 ppm gold by atomic absorption analysis.

The old pits at the Silver King prospect are in moderately to strongly sulfidized hornfels. Stibnite occurs in thin veins in the southernmost main pit and is accompanied locally by gold (sample 7A, table 1). Other samples from the Silver King pits contained from 0.08 to $6.2 \mathrm{ppm}$ gold in addition to markedly anomalous amounts of arsenic and copper; copper ranges from about $150 \mathrm{ppm}$ to 2 percent (20,000 ppm).

The composite vein or lode exposed in Colorado Creek south of the stock consists of distinct hanging and footwall veins in a 10-foot-wide shear zone. The largest vein fis ure in the lode, the one sampled, is about 4 feet wide; it contains stibnite and a small amount of gold (sample 9, table 1). A nearby vein (sample 10, table 1) assayed about 20 ppm gold, more than 10 percent antimony, and some lead and zinc.

Except in the canyon of Colorado Creek, exposures are very poor, and therefore it is possible that sulfidized rocks are much more widely distributed than 
presently known. The contacts of the mineralized rocks at the Silver King prospect and at the knob west of the pits are not exposed, but the mineral deposits at each place appear to be of either disseminated or brecciapipe type and could be explored by geophysical techniques, trenching, or drilling. Extensive sulfidization at both these places is indicated, particularly by the very high values of arsenic and iron, and at the Silver King by high copper values as well. The amounts of these elements near Colorado Creek are very similar to their abundances at the Golden Zone deposit, as may be seen by comparing the analyses in tables 1 and 2 .

Further evidence of mineralization in the Colorado Creek area is given by the anomalous metal values at and near the old Liberty and Lucrata prospects (Nos. 11,12 , and 13 , table 1 ).

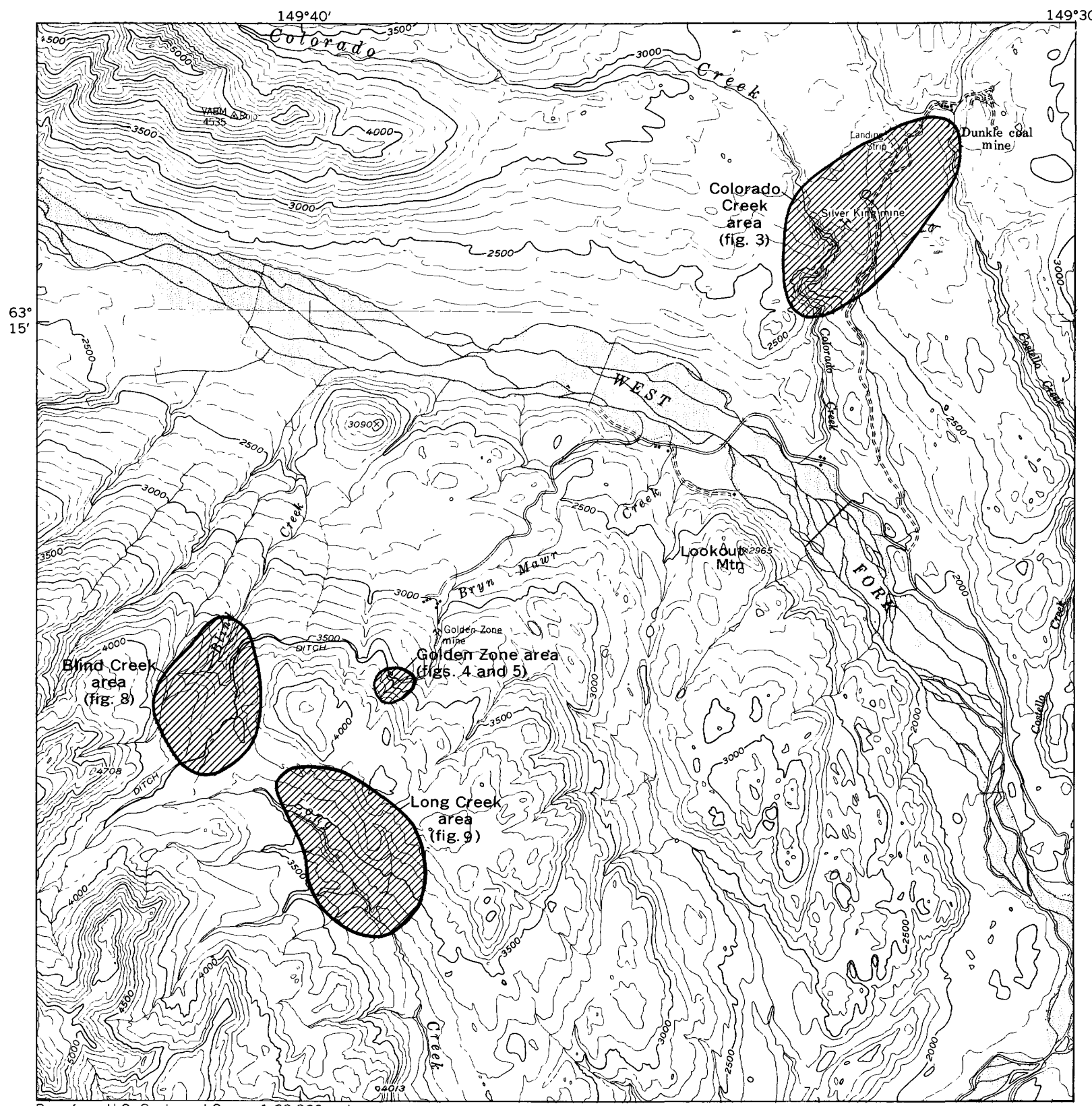

Base from U.S. Geological Survey 1:63,360 series:

Healy A-6, 1953 and Healy B-6, 1954

SCALE 1:63 360

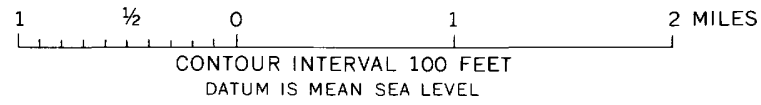

Figure 2.-Location of four mineralized areas in the upper Chulitna district. 


\section{GOLDEN ZONE AREA}

The Golden Zone mine area was described by Capps (1919, p. 226-227), Ross (1933, p. 321-325), and Hawley, Clark, and Benfer (1968), and the mine was sampled by the U.S. Bureau of Mines in 1950-51 (Mulligan and others, 1967). Claims were staked in the area as early as 1912, but production prior to 1941 is unknown. A little gold and silver were produced in 1941-42, but the mine has been inactive since.

The deposit is in and near a brecciapipe in a quartz diorite porphyry. Vein deposits of the area, not discussed in this report, include the Mayflower, East, Little, and Lindfors. The Golden Zone itself is held by assessment on the BOB group of claims by Cemco, Inc., of Anchorage, Alaska, whose General Manager, $H$. R. Beckwith, was helpful in furnishing information on ore grade and other data.
The Golden Zone area is largely underlain by volcanic siltstone and conglomerate of Permian or Triassic age (Ross, 1933) that were invaded by biotite quartz diorite porphyry, probably in early Tertiary time. The Golden Zone breccia-pipe deposit is approximately in the center of a small, very steep-walled porphyry stock (figs. 4 and 5). The deposit is in the brecciated and shattered material of the pipe and in adjacent parts of the quartz diorite porphyry. In approximate order of abundance, the metallic minerals of the deposit are arsenopyrite, pyrite, chalcopyrite, sphalerite, and galena. Trace amounts of mulybdenum and tin occur in the mineralized rock (table 2), and cassiterite was identified from the deposit by Walter Gnagy of the U.S. Bureau of Mines (written commun., 1967). The strongly mineralized rock is nearly white to very pale brown and has been strongly sericitized,

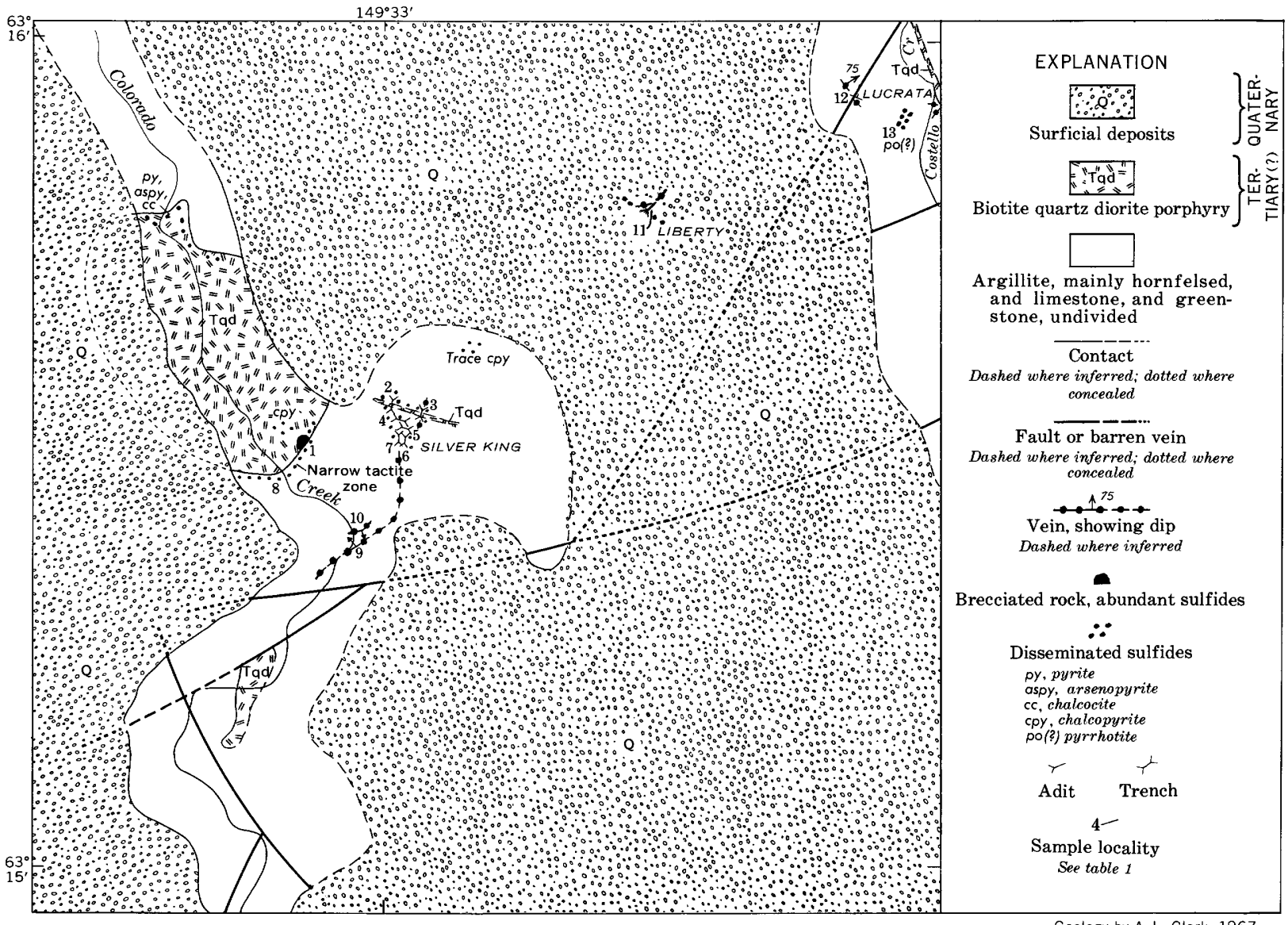

Geology by A. L. Clark, 1967

Figure 3.-Generalized geologic map of the Colorado Creek area. 
silicified, and carbonatized. The spectrographic analyses show anomalous amounts of boron, probably reflecting tourmaline which was identified in thin sections of the altered rock.

The breccia-pipe deposit is exposed at the surface and has been explored by two adits (fig. 4) and by numerous diamond-drill holes drilled from the 200-footlevel adit. One steep-angle hole ( $\mathrm{DH}-1) 1,025$ feet long was drilled by the U.S. Bureau of Mines in 1950-51 (fig. 5, section $\underline{B}-\underline{B}^{\prime}$ ). A long crosscut adit, the 500foot level (fig. 4) was begun in about 1939 but was abandoned about 900 feet from the deposit. None of the workings are presently accessible, but one segment of the contact of the breccia pipe is well exposed at the surface, and the drill core from the deep Bureau of Mines test has been preserved.

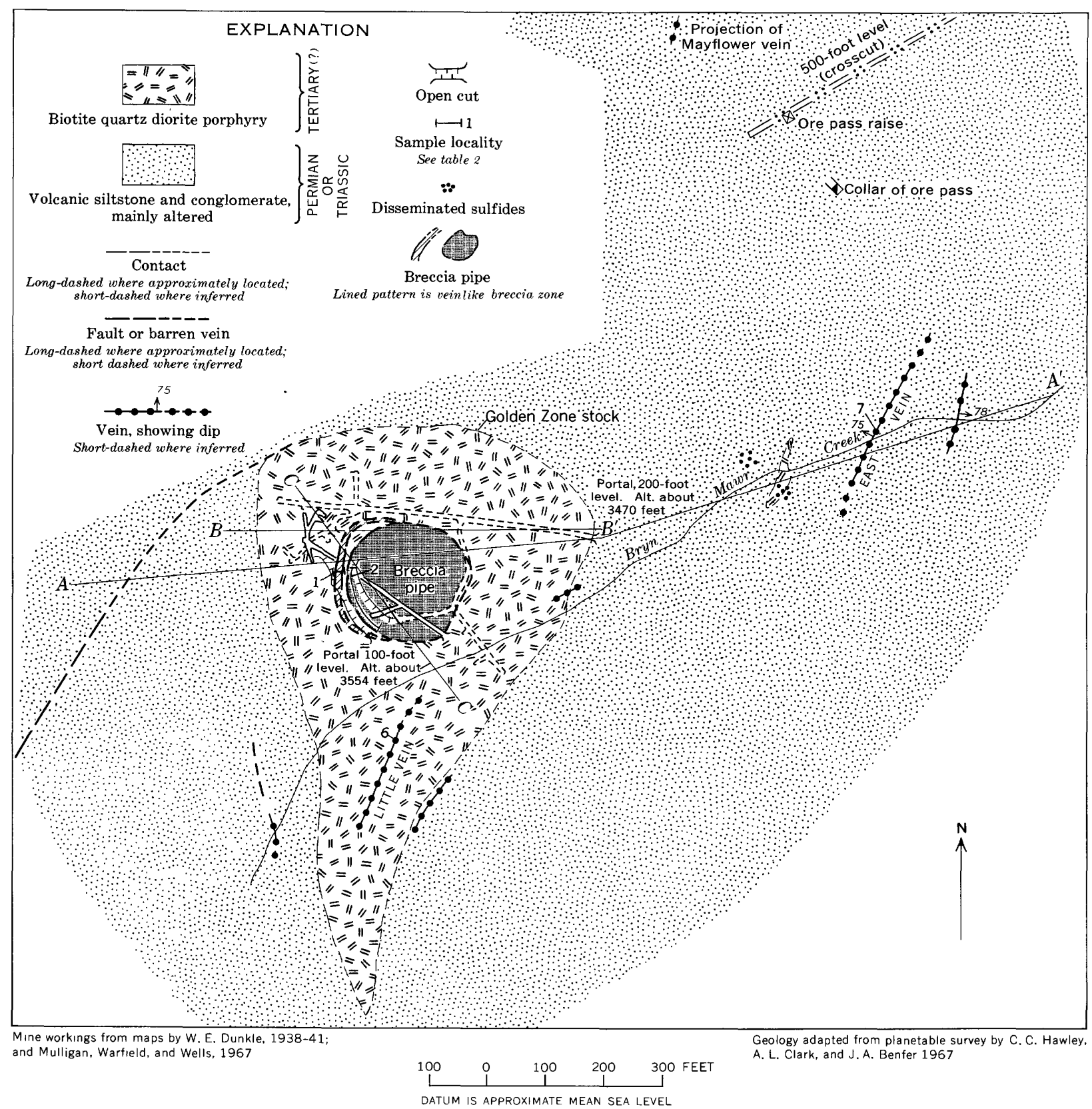

Figure 4.-Generalized geologic map of the Golden Zone mine area. 

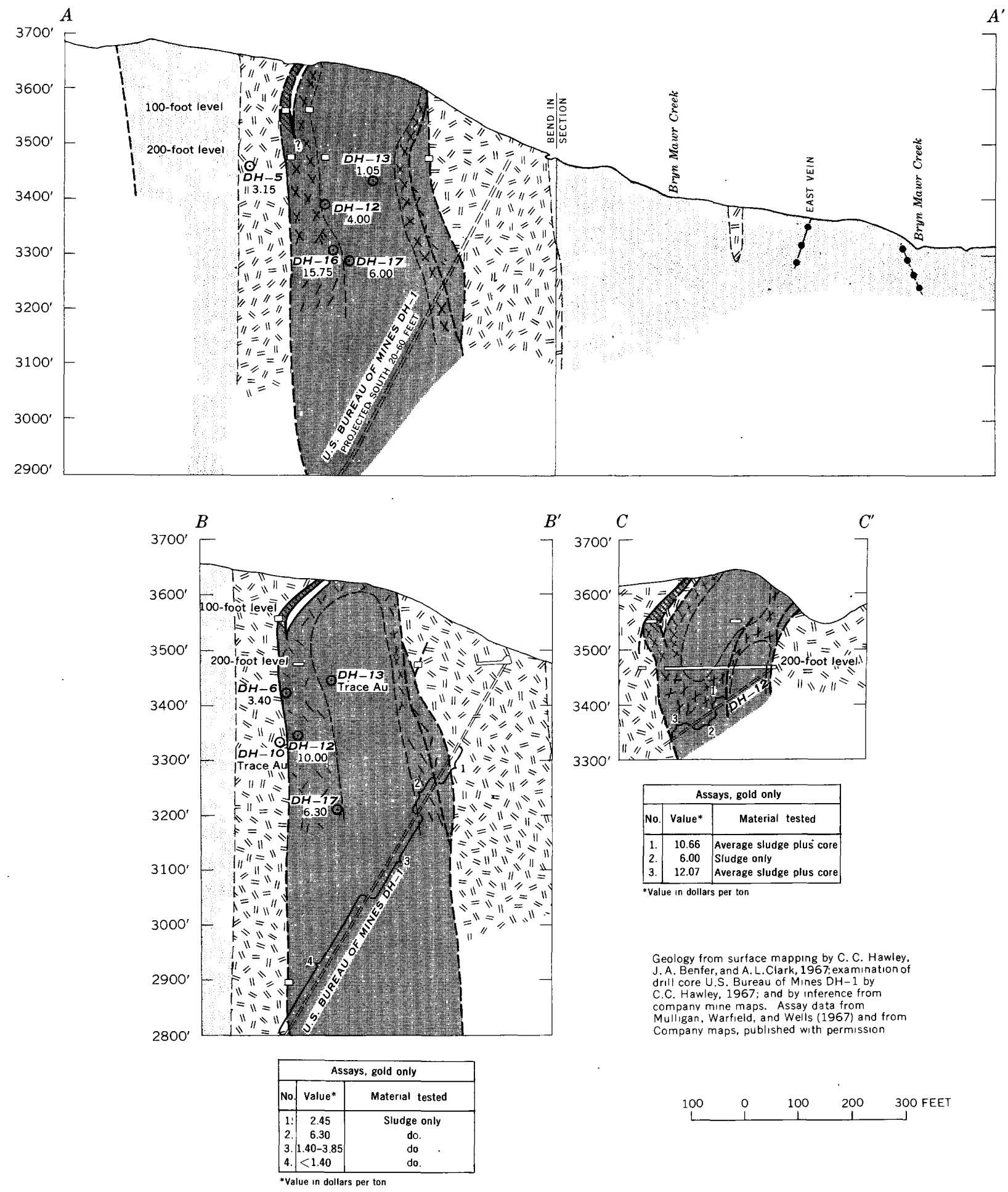

Figure 5.-Sections of the Golden Zone porphyry stock and breccia pipe. See figure 4 for location of lines of section. 
EXPLANATION

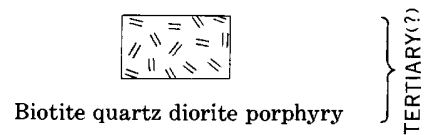
$\left.\begin{array}{c}\text { Volcanic siltstone and conglomerate } \\ \begin{array}{c}\text { Stippled where bleached or hornfelsed } \\ \text { Shown only on section }\end{array}\end{array}\right\} \underset{\sim}{\sum_{\frac{1}{u}}}$
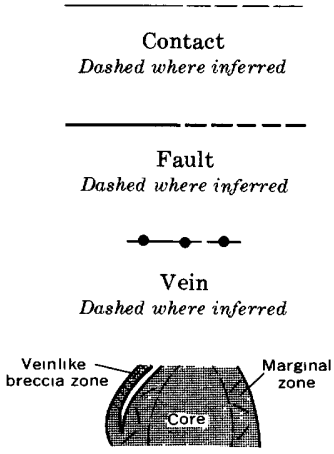

Breccia pipe

Halo shown on figures 6 and 7 indicates results of sampling and is not shown on sections. Dashed line bounding core indicates assay boundary and is shown in section only

$\odot$

Drill hole cut by section Show's gold value in dollars per ton in sludge at point of section

ニニニニニニニ二ニニニニ

Drill hole in or near plane of section

Mine openings

Figure 5.-Continued.
The Golden Zone breccia pipe is exposed on a small knob north of Bryn Mawr Creek, particularly in a shallow opencut (fig. 4). At the surface, the pipe is approximately circular in plan and is slightly more than 200 feet across. Drill holes and mine maps indicate that it enlarges slightly with depth. At an altitude of about 3,400 feet (fig. 5), the pipe appears to be about 200 feet long by slightly more than 250 feet across; at an altitude of 3,200 feet, the width, based on one projected and one drilled contact, is as much as 300 feet across. Judged by other breccia pipes described in the geologic literature, it is probably more complex than shown in figure 5. Two distinct zones of concentric fracturing probably are present in the pipe on the 200foot level-one zone coinciding with the marginal ore zone, discussed later, and a second, outer zone nearly coinciding with the curving drift driven southward from a point about 240 feet from the adit portal (fig. 4). The one deep drill hole in the pipe (section $B-\underline{B}^{\prime}$, fig. 5) shows that the pipe continues to a depth of at least 850 feet, and almost certainly to a much greater depth.

Exposures in the opencut and mine maps of the 100foot level (fig. 6) show a concentric veinlike breccia zone that encircles the western part of the pipe and is locally separated from it by slightly altered rocks. The rocks in this concentric zone are subrounded to angular blocks of porphyry that are strongly silicified and sericitized and are separated from other blocks by arsenopyrite-quartz-chalcopyrite-rich fillings. Some blocks appear to have been slightly rotated. The main part of the pipe, as exposed in the cut, has a sharp boundary, but is less fractured than the concentric breccia zone; its fragments only locally show evidence of rotation. The sulfide minerals in the main body of the pipe form fracture fillings and blobs in shattered, highly altered rocks.

\section{Economic Significance of the Deposit}

The ore grade of the Golden Zone breccia pipe varies and has proved to be difficult to determine by drilling (Mulligan and others, 1967). It seems probable, however, that a relatively high-grade part approximately coincides with a strongly fractured zone that bounds the pipe. This zone, called the marginal zone, encloses a core of weakly mineralized rock and in turn is enclosed in a halo of altered and weakly mineralized rock.

The marginal zone is exposed in an opencut at the surface and is fairly well defined on the 100 -foot level by assay values (fig. 6). On the 100-foot level, the outer part of the marginal zone is a breccia of veinlike form that appears to be from 15 to 25 feet wide and to average, on the basis of channel samples cut by other geologists and engineers, $0.30 \mathrm{oz}$ (ounce) gold 
per ton, $2.94 \mathrm{oz}$ silver per ton, and about 0.9 percent copper. The outer boundary of the marginal zone is defined by a fault contact; the inner boundary is probably gradational. On the basis of unpublished geologic maps of the 100-foot level, which show strongly mineralized rocks close to the veinlike breccia, the entire marginal zone is estimated to be about 60 feet across. In the opencut, the veinlike breccia zone is about 15 feet across and assays about $0.45 \mathrm{oz}$ gold per ton, and $3 \mathrm{oz}$ silver per ton $(15 \mathrm{ppm}$ and $100 \mathrm{ppm}$ respectively, sample 2 , table 2 ). The sample shows marked concentrations of bismuth, cadmium, copper, lead, tin, and zinc. The rock in the main body of the pipe in the opencut (sample 1) contains slightly less than $0.1 \mathrm{oz}$ gold per ton, about $6 \mathrm{oz}$ silver per ton, and anomalous amounts of the same elements as sample 2 .

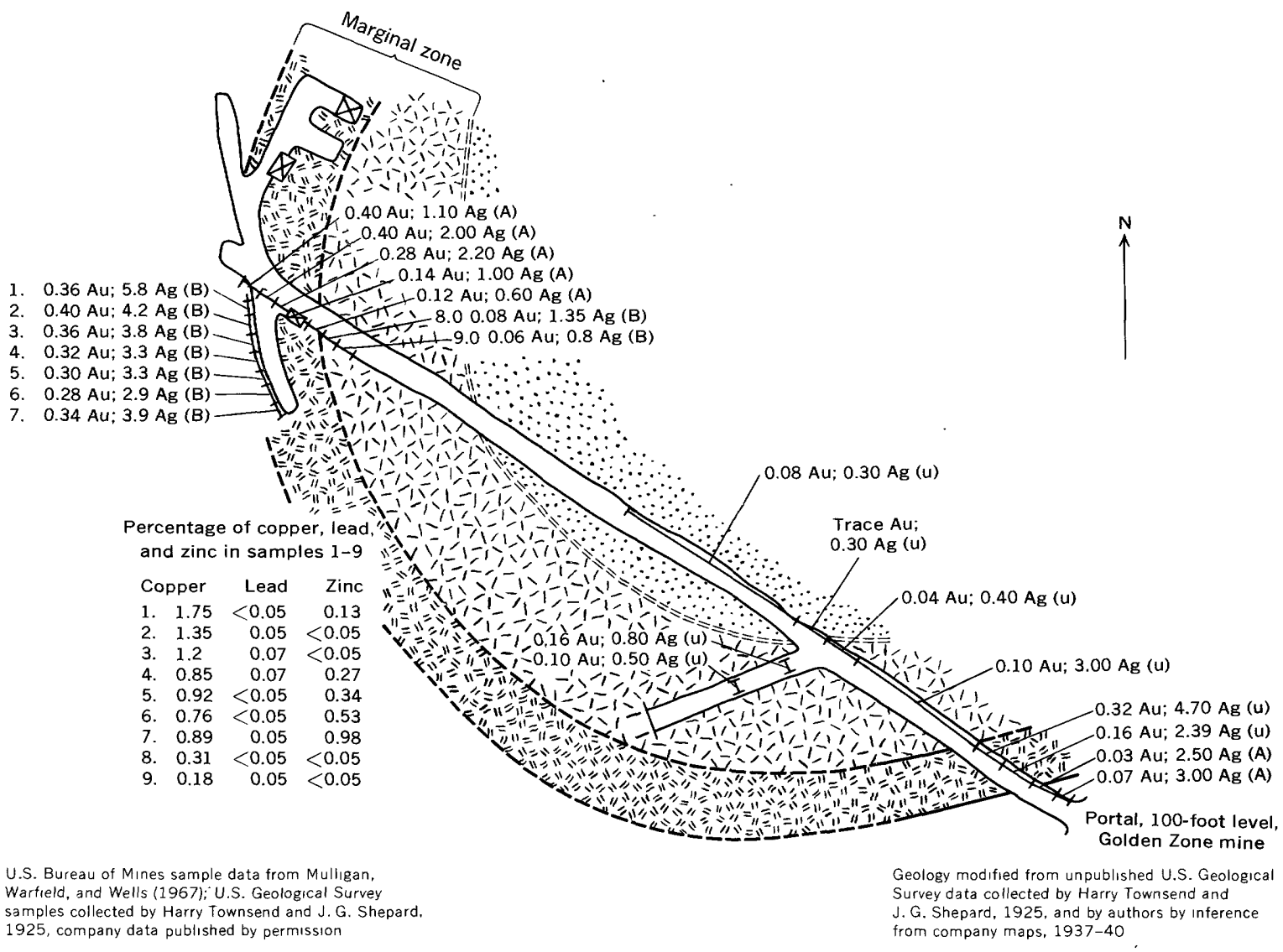

Warfield, and Wells (1967); U.S. Geological Survey

1925, company data published by permission

Survey data collected by Harry Townsend and
J. G. Shepard, 1925, and by authors by inference

from company maps, 1937-40

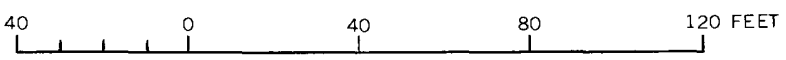

E $X \quad P \quad L \quad A \quad N \quad A \quad T \quad I O C N$
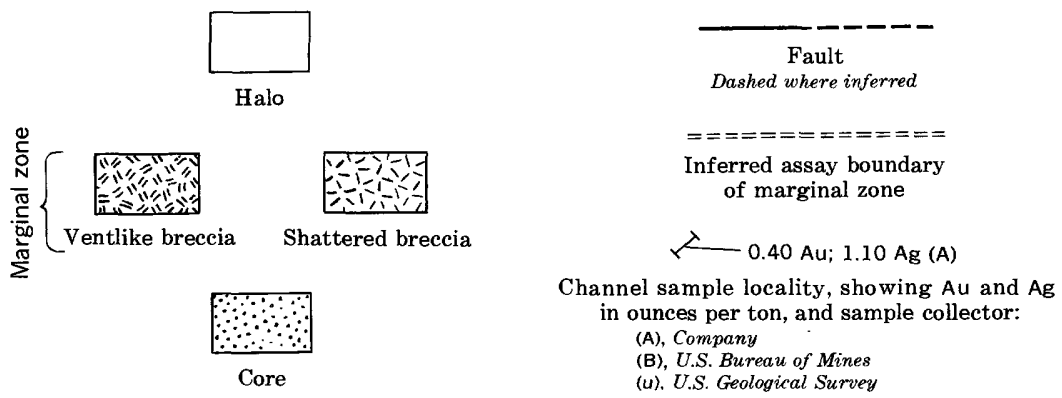

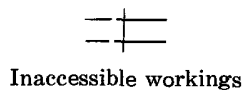

$\otimes$

Raise

Figure 6.-Generalized geologic map showing assay data, 100-foot-level adit, Golden Zone mine. 
On and near the 200-foot level, numerous assays from channel samples or sludge from low-angle drill holes suggest an oval-shaped marginal zone, with maximum dimensions of about 120 by 240 feet, enclosed in a weakly mineralized halo about 370 by 500 feet across (fig. 7). Assays in the marginal zone range from about $0.06 \mathrm{oz}$ gold per ton to more than $0.6 \mathrm{oz}$ per ton and average about $0.21 \mathrm{oz}$ per ton; less abundant assay data suggest a value of from $\$ 1$ to $\$ 3$ for other metals, principally silver and copper. The core area, although penetrated by some drill holes, is essentially of unknown value. The average assay value of 228 samples in the halo area is about $0.04 \mathrm{oz}$ gold per ton. Although most samples in this zone contain $0.01 \mathrm{oz}$ gold or less per ton, widely scattered samples or groups of samples contain more, thereby raising the average significantly. As noted above, the ovalshaped marginal ore zone on the 200-foot level is probably surrounded in part by an arcuate zone of strong fracturing, and groups of assays from this zone, particularly in the curving drift south and west 240 feet from the portal (fig. 7), are higher in value than the general average of the halo. This suggests in turn, that more detailed work in the halo may delineate zones distinctly richer than the average.

The only check on the grade of the deposit as estimated from channel samples or drill core and sludge is from mining in 1941-42, when the Golden Zone produced 869 tons of concentrates that contained 1,581 oz gold, 8,617 oz silver, and 42,659 lbs copper (Mulligan and others, 1967). According to H. R. Beckwith of Cemco, Inc. (written commun., 1967), these concentrates came from about 1,730 tons of ore yielding an average grade, from one lot of 1,480 tons, of approximately $0.99 \mathrm{oz}$ gold per ton, $4.5 \mathrm{oz}$ silver per ton, and 1.4 percent copper; a second lot of 250 tons was of lower grade, but both lots were appreciably higher than the grade determined by channel sampling. It seems apparent from the location of the opencut and of raises on the 100- and 200-foot levels (figs. 6, 7) that this ore was mined largely from the marginal zone. The tonnage figure seems reasonable for the short period of mining activity, the size of the mill, and the amount of tailings, and so the grade of the deposit may have been underestimated by conventional sampling.

Although the grade and subsurface dimensions of the deposit are imperfectly known, rough calculations based on assays from the 200-foot level indicate a likelihood of about 260,000 tons of material, containing possibly $0.14 \mathrm{oz}$ gold per ton, per 100 feet of depth. The fairly abundant assay data from surface, underground workings, and drill holes down to about 400 feet also permit a rough calculation of the hypothetical value of metals in the upper part of the deposit. Calculations from these data show about $\$ 10,000,000$ worth of metals in the upper 400 feet of the deposit, including the marginal zone and the appreciably lower grade core and halo. The single deep U.S. Bureau of Mines drill hole shows that the pipe extends to at least 850 feet in depth and is at least weakly mineralized below 400 feet, so that the $\$ 10,000,000$ figure is minimal. Furthermore, if the value of metals has been underestimated by conventional sampling, as data on the 1941-42 production suggest, the $\$ 10,000,000$ value is too small. The deposit appears to warrant further study and exploration.

Particular attention should be given to the possibilities of vertical or horizontal zoning in the pipe. The possibility of vertical zoning is suggested principally by the complex metal assemblage in the Golden Zone and nearby deposits. Horizontal zoning in the deposit itself is apparently indicated by data from U.S. Bureau of Mines drill hole 1, which shows an inverse correlation of copper with gold at the eastern edge of the pipe, with copper enriched relative to gold just outside the pipe.

\section{BLIND CREEK AREA}

The Blind Creek area (fig. 8) is about 1 mile west of the Golden Zone and is mainly underlain by volcanic siltstone and conglomerate. It is cut by a major fault zone striking north-northeast which records a late period of strike-slip deformation by nearly horizontal slickensides. Locally the fault zone contains quartz veins and quartz-cemented breccia zones as much as 200 feet across. The quartz ranges from white and massive to a faintly opalescent type with a colloform structure; locally it is limonite stained or contains pyrite.

Assays of the quartz veins and associated pyritic material show very minute amounts of gold, although none was seen. Two samples were collected; sample $\mathrm{BC}-1$ (table 2) was a composite grab sample of quartz and limonitic quartz collected from residual fragments in the soil over a distance of several hundred feet. It contains slightly more gold $(0.06 \mathrm{ppm})$ than the detection limit $(0.02 \mathrm{ppm})$. Sample BC-2 (table 2) was a short (2.0-foot chip) sample collected over a strongly pyritic part of the vein; it contains slightly more gold $(0.30 \mathrm{ppm})$ but still not in amounts approaching commerical value. The samples also contain measurable amounts of silver, trace or greater amounts of arsenic, and one sample shows $150 \mathrm{ppm}$ lead and a trace of zinc ( $<200 \mathrm{ppm})$.

Although the Blind Creek occurrence has no apparent economic value, it is reported because of the large size of the quartz veins and because the controlling Blind Creek fault zone apparently is a major premineral throughgoing structure.

\section{LONG CREEK AREA}

The Long Creek area (fig. 9) is south of the Golden Zone and appears to have a slightly different type of mineralization. Copper sulfides occur widely in small 
amounts and are concentrated near the Copper King prospect. The copper minerals occur in veins, in massive replacement of favorable strata, and disseminated in bleached areas in predominantly red volcanic siltstone and conglomerate.

The Copper King prospect, once known as the Hector, is on land restaked by Mark Ringstad, Fairbanks, in April 1967. The workings consist of several shallow trenches, all of which expose copper minerals. Massive chalcopyrite and pyrrhotite are exposed as a lensoid mass about 5 feet thick in trench No. 3 (sample location 2 and 3 ).

The trenches are all in hornfelsed locally calcareous siltstone, which is cut by small dikes and plugs of quartz porphyry. The quartz porphyry and adjacent hornfels are cut by siliceous veinlets on several fracture trends, and the siliceous veinlets contain very sparse amounts of molybdenite, chalcopyrite, and pyrite. The molybdenite is seemingly more abundant in the quartz porphyry than in the hornfels, and the pattern of mineralization suggests a zonal distribution of copper around the quartz porphyry masses.

Samples from the main trenches at the Copper King (Nos. 1-4, Long Creek area, table 2) contain from about 0.5 to 2 percent copper, 1 to 3 oz silver per ton, gold worth about $\$ 1$ to $\$ 8$ per ton, and detectable amounts of bismuth, zinc, and tin. Mineralized rock from the prospect is also represented by sample 6, a grab sample of sacked ore that is probably from the same trench as samples 2 and 3. Molybdenum, visibly

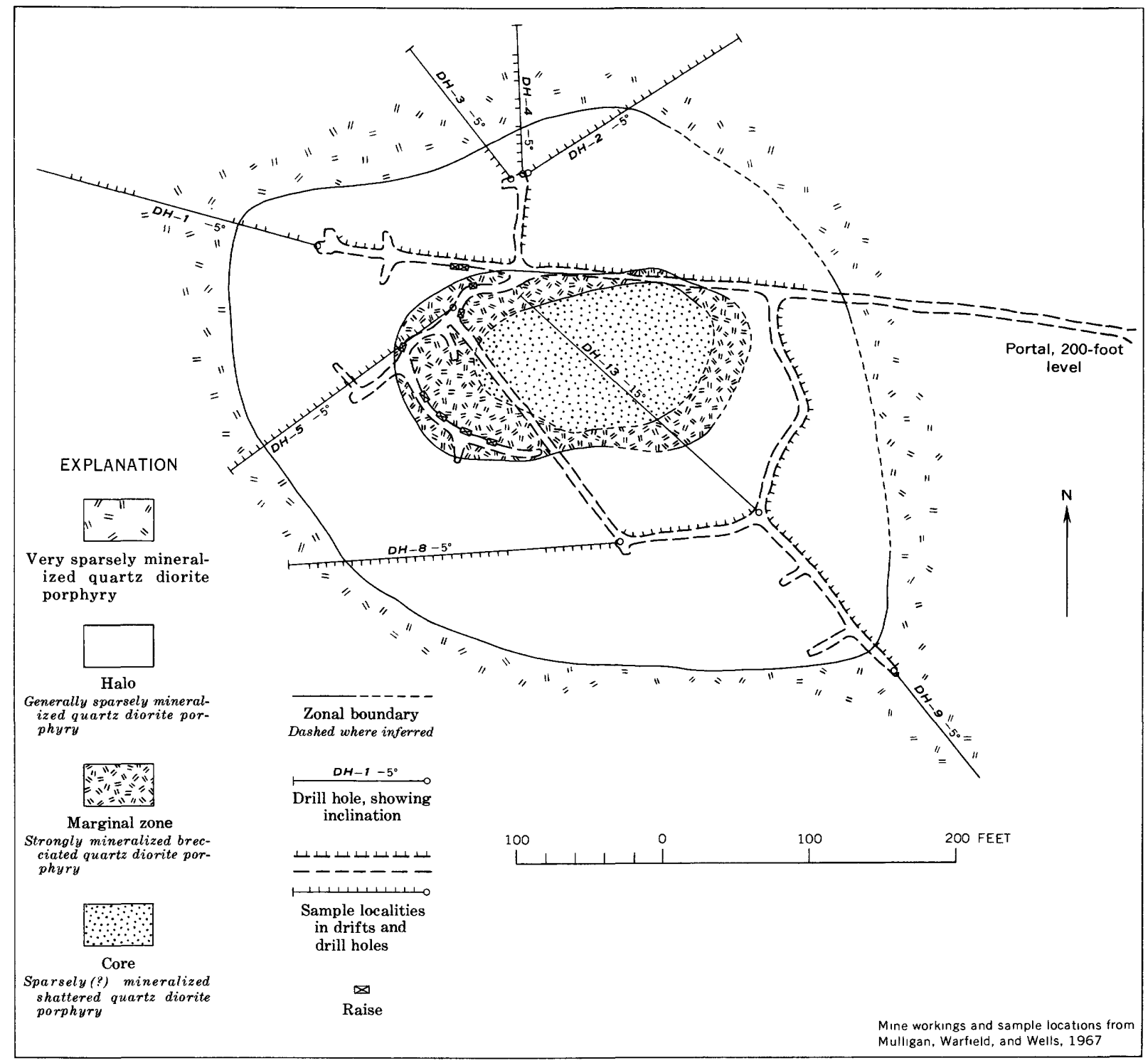

Figure 7.-Distribution of mineralized rock, 200-foot-level adit, Golden Zone mine. 
present as molybdenite in veinlets in quartz porphyry near the prospects, was not detected at the prospect, but was found in a trace amount $(15 \mathrm{ppm})$ in weakly veined porphyry (sample 5).

\section{Conclusions and Recommendations}

The known copper mineral occurrences of the Long Creek area are small but are locally rich in copper; the molybdenite deposits are small and of very low grade. Nevertheless, the sulfide mineral occurrences are numerous and widespread. Because of this and the apparent association of deposits with quartz porphyry, more exploration of the area is justified. Geophysical exploration, particularly by induced polarization, would be desirable, as well as additional trenches and shallow drill holes.

\section{STREAM-SEDIMENT SAMPLES}

Anomalous amounts of gold and other elements are found in some stream-sediment samples from the district (fig. 10 and table 3 ). The largest anomalous values in gold are in Bryn Mawr and Colorado Creeks.
Sample 24 from Bryn Mawr Creek was taken just below the Golden Zone mine, where any naturally occuring gold may have been augmented by gold from the mine debris. However, two uncontaminated rightlimit tributaries to Bryn Mawr Creek, represented by samples 17 and 27, are also anomalous, indicating bedrock mineralization in their headwaters. Sample 12, from near the mouth of Bryn Mawr, while not anomalous in gold, is highly anomalous in arsenic and copper (table 3 ), as is sample 11 from an adjacent stream. Since mining activity in and near the Silver King prospect has probably not been extensive enough to contaminate Colorado Creek, sample 8 is believed to approximately represent the natural gold value of the stream. The drainage nearest the Copper King prospect, sample 43 , has detectable amounts of silver and arsenic, but little else to indicate mineralization.

With the exception of sample 9, most anomalous gold values are in a linear belt that extends northeast from near the head of Long Creek to Colorado Creek, or subparallel to the major direction of faulting recognized in the district by Ross (1933).

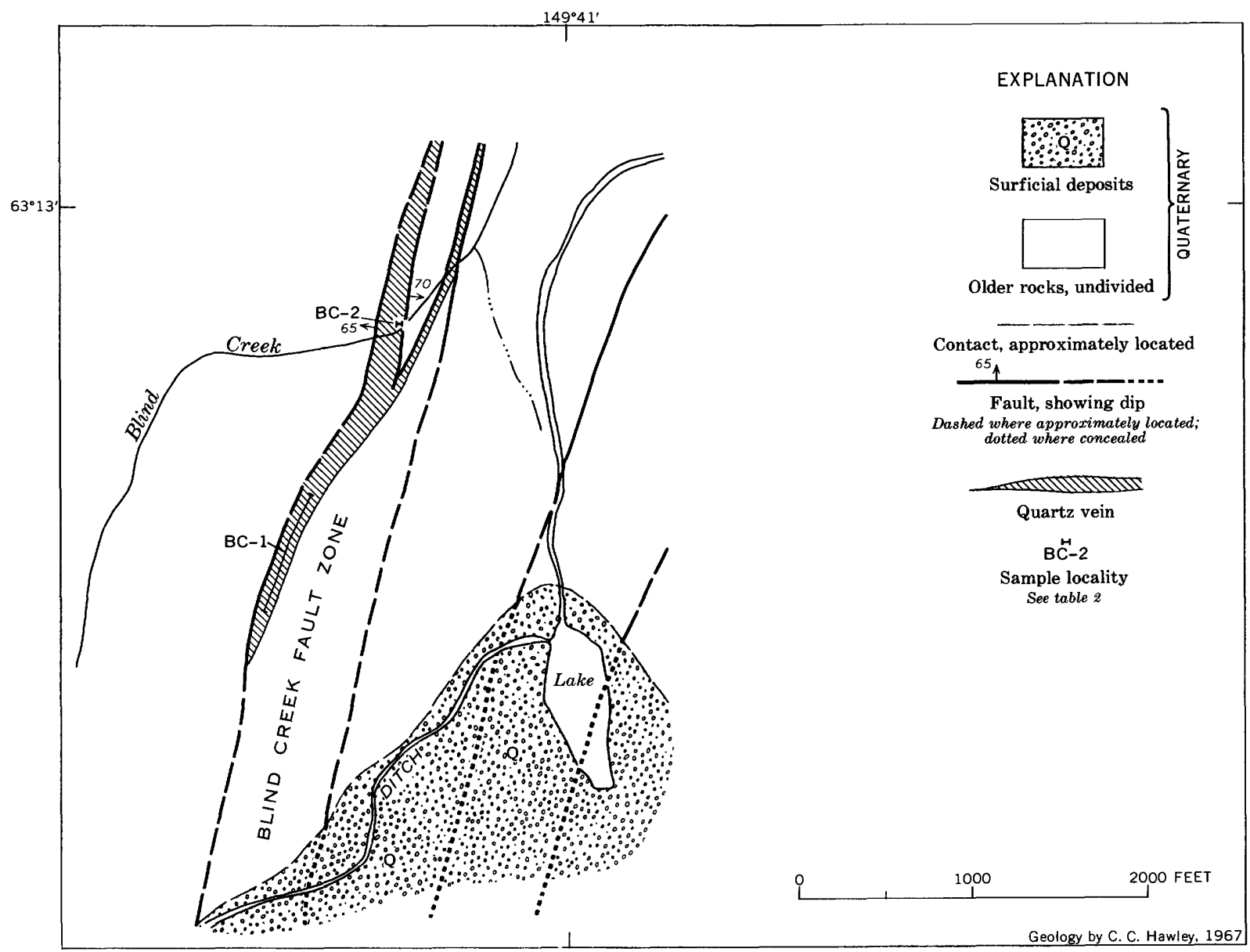

Figure 8.-Generalized geologic map of the Blind Creek area. 


\section{DISTRICTWIDE SUMMARY AND RECOMMENDATIONS}

Gold and other metals are concentrated at several places in the upper Chulitna district, in particular, the Colorado Creek, Golden Zone, and Long Creek areas. Trace amounts of gold occur in strong quartz veins of the area, as at Blind Creek. Many more mineral occurrences, particularly of vein type, are known, and, because surficial deposits cover much of the district, probably many deposits are buried. The dominant structural grain of the region is north- easterly, and scattered mineral occurrences known both northeast and southwest of the district indicate that the full extent of the district is not known. We believe that more prospecting is justified in the area, particularly in Colorado Creek and near the Golden Zone deposit. Our experience indicates that there are outcropping mineral occurrences to be found, but because of the cover by surficial deposits, geophysical prospecting seems particularly appropriate in a search for new disseminated and breccia-pipe mineral deposits.

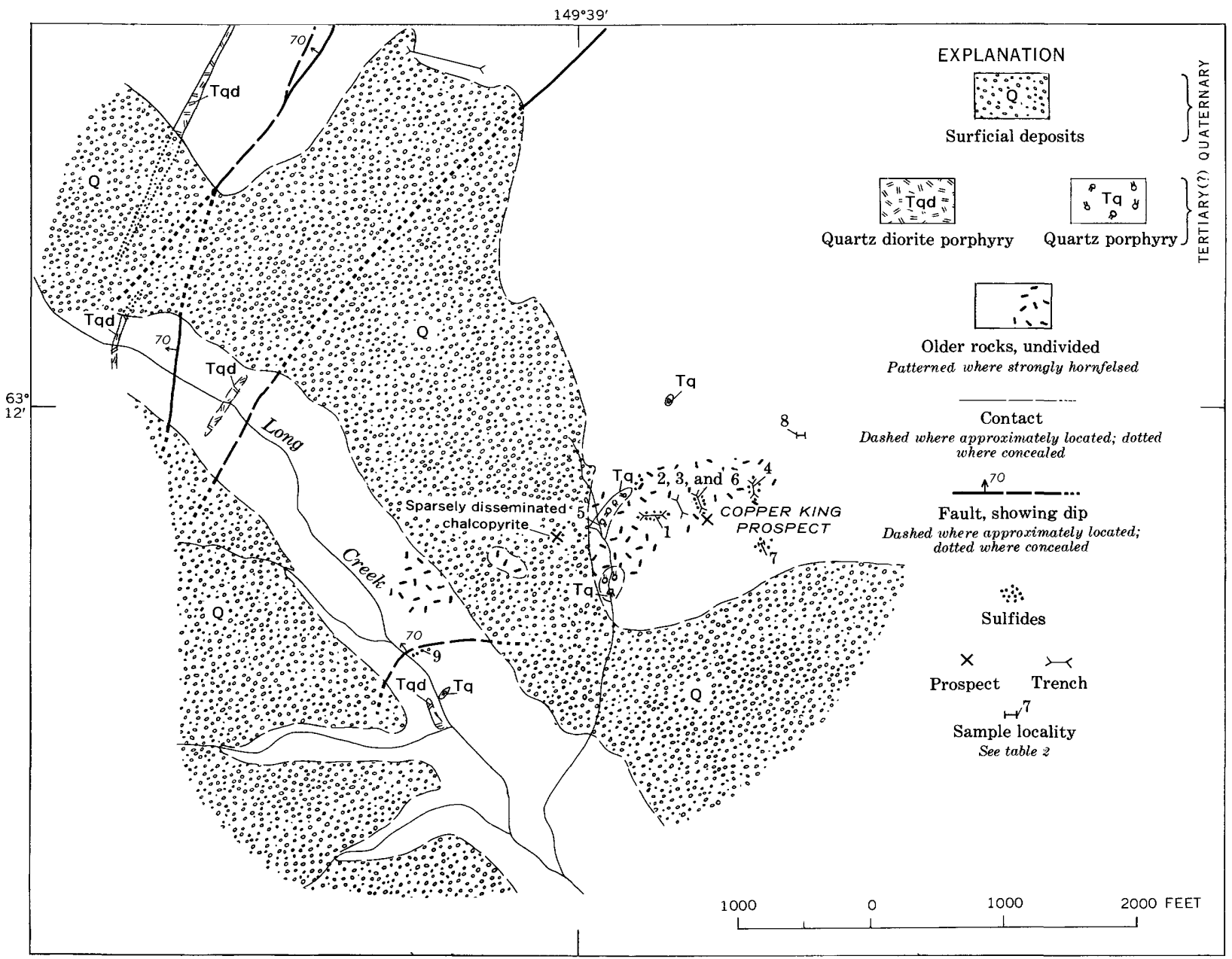

Geology by C. C. Hawley, 1967

Figure 9.-Generalized geologic map of the Long Creek area. 


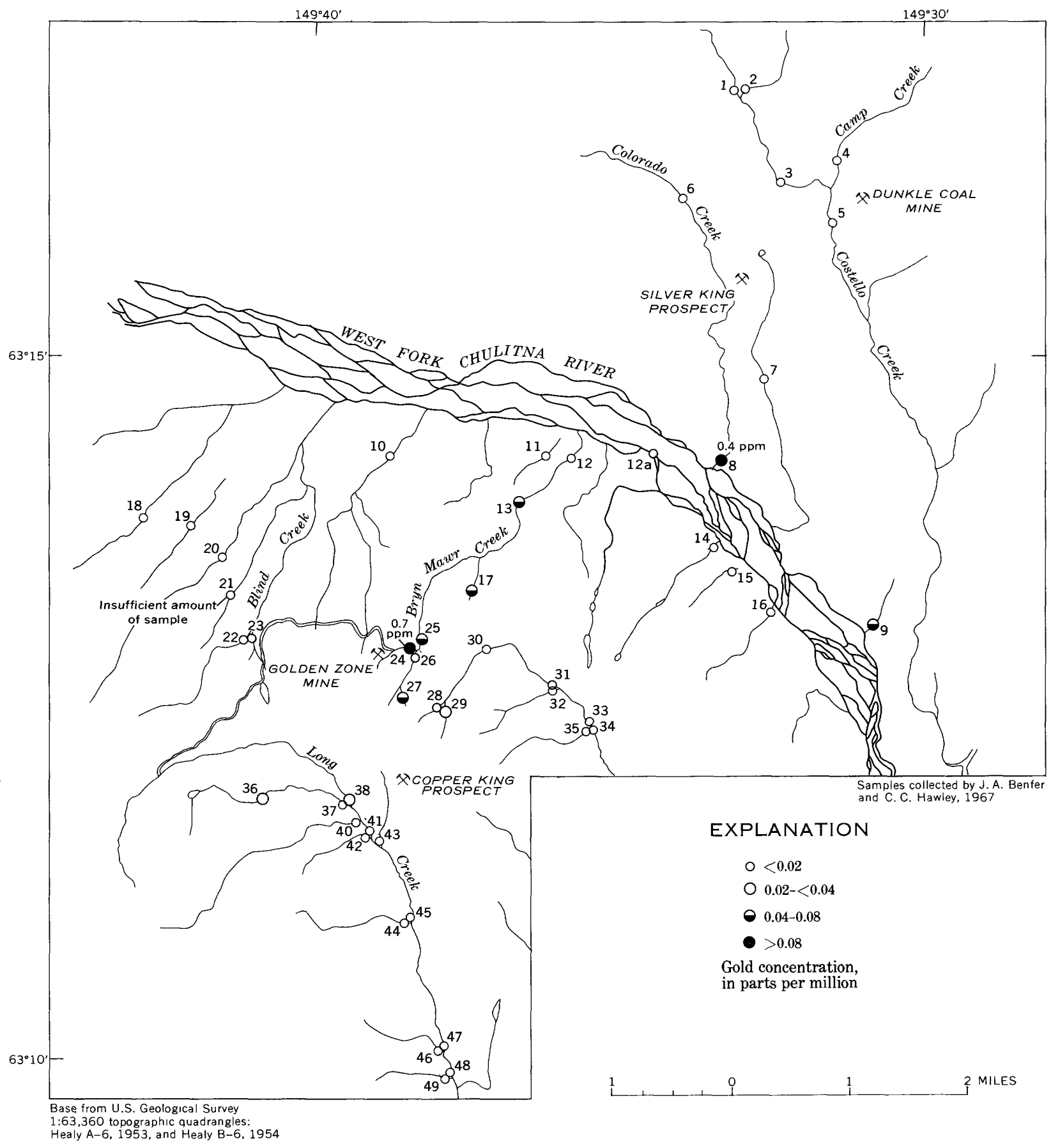

Figure 10.-Location and gold concentration of stream-sediment samples, upper Chulitna district.

\section{REFERENCES}

Capps, S. R., 1919, Mineral resources of the upper Chulitna region [Alaska]: U.S. Geol. Survey Bull. 692, p. 207-232.

Hawley, C. C., Clark, Allen L., and Benfer, J. A., 1968, Geology of the Golden Zone mine area, Alaska: U.S. Geol. Survey open-file rept.
Mulligan, J. J., Warfield, R. S., and Wells, R. R., 1967, Sampling a gold-copper deposit, Golden Zone mine, south-central Alaska: U.S. Bur. Mines open-file rept.

Ross, C. P., 1933, Mineral deposits near the West Fork of the Chulitna River, Alaska: U.S. Geol. Survey Bull. 849-E, p. 289-333. 
Table 1.-Analyses of samples from

[Analyses, except of gold, are semiquantitative spectrographic by D. J. series $0.1,0.15,0.2,0.3,0.5,0.7,1.0,1.5$, and so on, or by the following ---, not looked for. Results are given in parts per million except for sorption are by W. L. Campbell and A. L. Meier. Gold analyses by fire Samples: Localities are shown in figure 3; all are chip samples; lengths

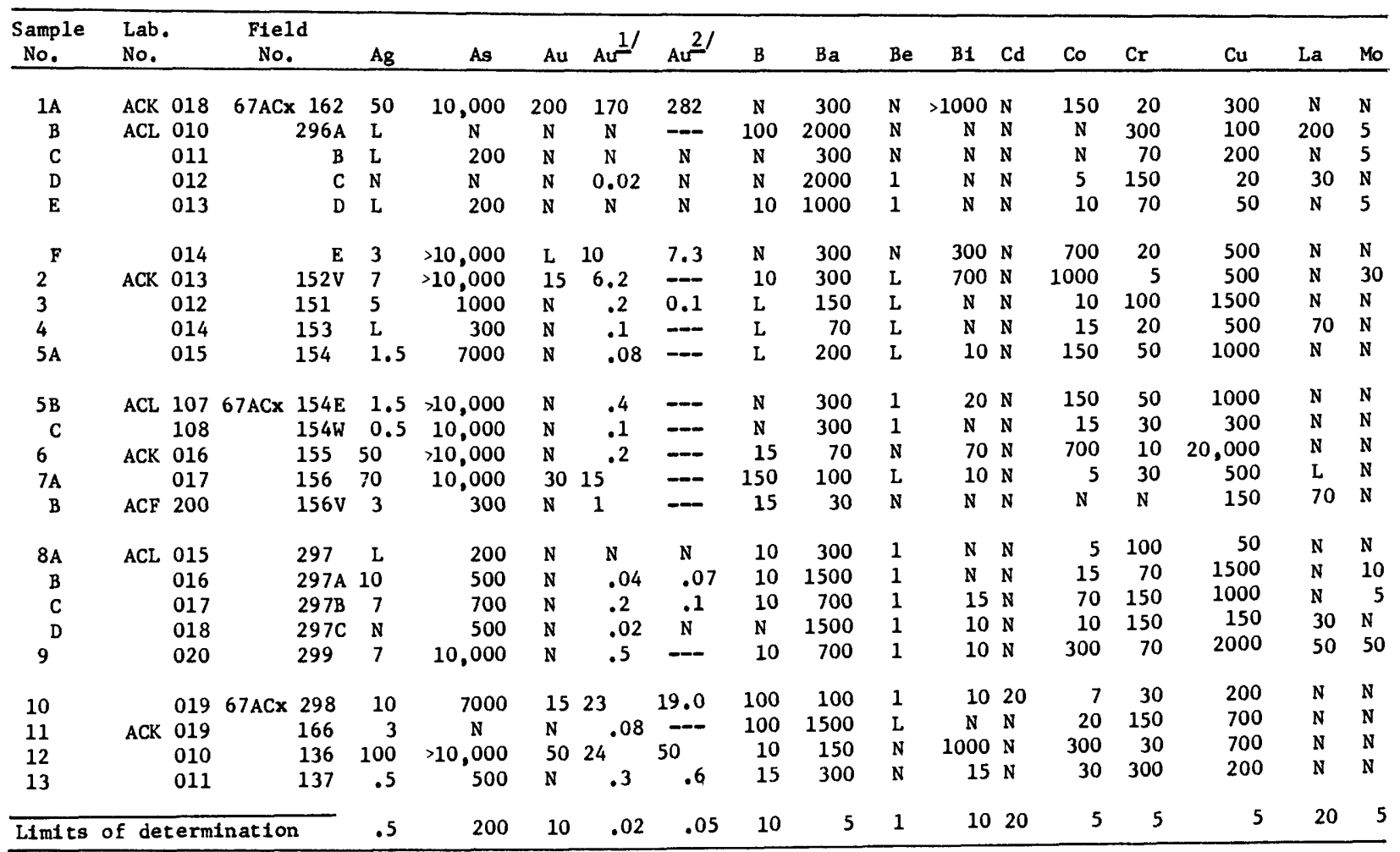

$\frac{1}{2}$ Atomic absorption.

$\frac{2}{3}$ Fire assay or fire assay-atomic absorption.

Specific instrumental or chemical method.

\section{Location Sample No. and description}

1 - . . . 1A, 2-foot. Hornfels with abundant arsenopyrite, pyrite, and limonite.

1B, 1-foot. Hornfelsed a rgillite, weakly mineralized with disseminated arsenopyrite.

1C, 3-foot. Hornfels, pervasively stained by limonite.

ID. Biotite quartz diorite, altered to clay and sericite.

1E. Hornfels marginal to ID.

IF, 6-inch. Massive sulfide veinlet. Primar ily arsenopyrite, pyrite, and quartz. Weak copper (azurite) stain.

\section{Location Sample No. and description}

$2 \ldots . .-2,2$-foot. Vein material, primarily arsenopyrite. Strongly limonite-stained.

$3 \ldots . . .3,1$ - foot. Sericitized quartz diorite with strong limonite gossan.

$4 \ldots \ldots$. . . 4. Hornfels near limonite-stained fault zone. Strongly sheared.

5 - . - 5 5, 8-foot. Altered hornfels near face of small prospect pit. Contains minor arsenopyrite: pervasive limonite stain.

5B, 10-foot. Same as 5A on east side of pit. 5C, 10-foot. Same as 5A on west side of pit. 
Grimes, E. E. Martinez, and R. T. Hopkins, Jr., and are reported in the symbols: N, not detected; L, detected but below limit of determination; $\mathrm{Fe}, \mathrm{Mg}, \mathrm{Ca}, \mathrm{Ti}$, which are given in percent. Gold analyses by atomic abassay-atomic absorption are by W. D. Goss and Claude Huffman, Jr. shown with description where known]

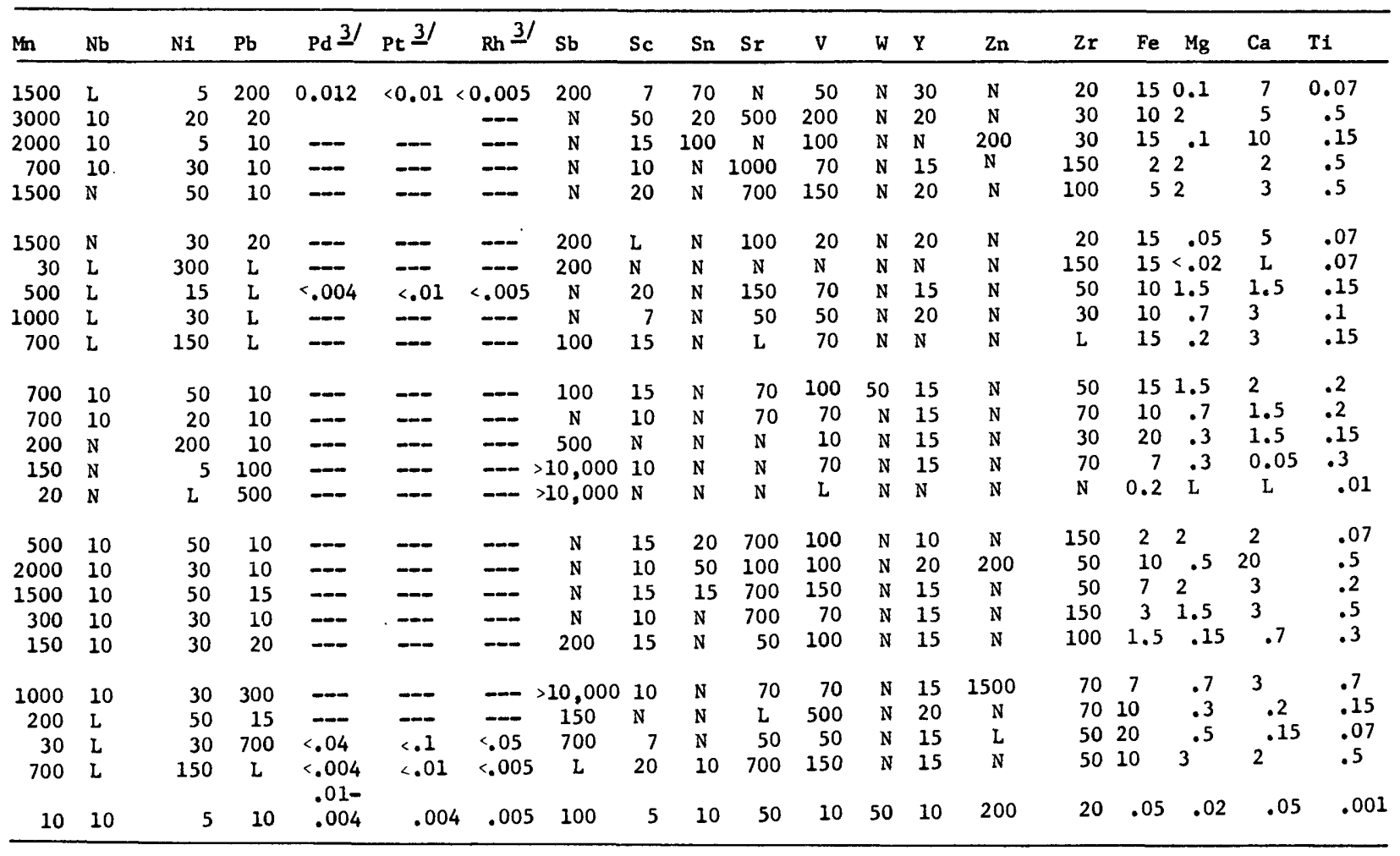

\footnotetext{
Location Sample No. and description

6 - . - 6. Contact zone between altered quartz diorite and hornfels that contains disseminated arsenopyrite.

7 - . . - 7A, 6-inch. Hornfels containing disseminated arsenopyrite and stibnite.

7B, 1-foot. Arsenopyrite vein containing minor stibnite.

$8 \ldots-\ldots$ - . 8 A, 14-inch. Tactite at margin of quartz diorite plug. Tactite is mainly composed of magnetite, epidote, garnet, and actinolite. $8 \mathrm{~B}, 14$-inch. Same zone as $8 \mathrm{~A}$.

$8 \mathrm{C}, 1$-foot. Hornfels peripheral to tactite zone.
}

\section{Location Sample No. and description}

$8 \ldots-2$ - 8 D. Chip of altered quartz diorite associated with tactite and hornfels of $8 \mathrm{~B}$ and $8 \mathrm{C}$.

9 - . . . 9, 4-foot. Arsenopyrite vein, sparse stibnite. Vein is on footwall of 10 -foot shear zone, 1 - to 2 -foot hanging-wall vein inaccessible.

10 - . . 10, 1 -foot. Stibnite-pyrite vein material.

11 - . . - 11. Gossan d eveloped from arsenopyritepyrite veinlets in altered hornfels.

$12 \ldots . .12$. Arsenopyrite-pyrite vein with minor quartz.

$13 \ldots \ldots$ - . 13, 2-foot. Hornfels containing disseminated pyrrhotite(?). 
Table 2.-Analyses of samples from the Golden

[Analyses, except of gold, are semiquantitative spectographic by Arnold series $0.1,0.15,0.2,0.3,0.5,0.7,1.0,1.5$, and so on, or by the following not looked for. Results are given in parts per million except for $\mathrm{Fe}$, are by A. L. Meier, R. L. Miller, and T. A. Roemer. Gold analyses by

\begin{tabular}{|c|c|c|c|c|c|c|c|c|c|c|c|c|c|c|c|c|c|}
\hline $\begin{array}{l}\text { Sample } \\
\text { No. }\end{array}$ & $\begin{array}{l}\text { Lab. } \\
\text { No. }\end{array}$ & $\begin{array}{c}\text { Field } \\
\text { No. }\end{array}$ & Ag & As & Au & $\mathrm{Au}=1 /$ & $\mathrm{Au}^{2}$ & B & $\mathrm{Ba}$ & $\mathrm{Be}$ & B1 & $\mathrm{Cd}$ & Co & Cr & $\mathrm{Cu}$ & La & Mo \\
\hline & & olden Zone & area & (sample 1 & local & Lities & shown & in $f t$ & . 4) & & & & & & & & \\
\hline 1 & ACF 117 & 67AHx & 200 & 7000 & $\mathrm{~N}$ & 4.2 & 1.9 & 150 & 700 & 1 & 30 & 200 & L & 100 & $>5000$ & 30 & $\mathbf{N}$ \\
\hline 2 & 116 & 42 & 100 & 10,000 & 10 & 15 & 14.8 & 150 & 700 & $\mathrm{~N}$ & 50 & 50 & $\mathbf{L}$ & 30 & $>5000$ & 30 & $\mathrm{~N}$ \\
\hline 3 & 119 & 46 & 20 & $>10,000$ & $\mathbf{N}$ & 5 & 5.3 & 100 & 500 & 1 & 70 & 20 & 20 & 70 & 1500 & 20 & $\mathbf{N}$ \\
\hline 4 & ACE 627 & 46D & 10 & 3000 & $\mathbf{N}$ & .4 & $-\infty$ & 200 & 300 & 1 & $\mathrm{~N}$ & 30 & 10 & 50 & 500 & $<50$ & L \\
\hline & $9-255$ to & D128680 & & & & & & & & & & & & & & & \\
\hline 5 & $9-272$ & -128697 & 2 & 3000 & $\mathbf{N}$ & .8 & - & - & 500 & 1 & $\mathbf{L}$ & $<50$ & 10 & 150 & 200 & $<30$ & 23 \\
\hline 6 & ACF 118 & $67 \mathrm{AHX} \quad 45$ & 30 & $>10,000$ & 20 & 25 & 25.0 & 70 & 150 & $\overline{\mathbf{N}}$ & 200 & 20 & $\mathrm{~N}$ & 10 & 300 & 20 & $\mathrm{~N}$ \\
\hline 7A & 011 & $128 \mathrm{~A}$ & 150 & $>10,000$ & 10 & 9.4 & $-\infty$ & 15 & $\mathbf{N}$ & $\mathrm{L}$ & 30 & 300 & 15 & L & 1000 & $\mathbf{N}$ & $\mathbf{N}$ \\
\hline $7 \mathrm{~B}$ & 012 & $128 \mathrm{~B}$ & 100 & $>10,000$ & $\mathbf{L}$ & 4.2 & - & 50 & 200 & L & $\mathbf{L}$ & 500 & 10 & 100 & 500 & $\mathbf{N}$ & $\mathbf{N}$ \\
\hline
\end{tabular}

Blind Creek area (sample localities shown in fig. 8)

\begin{tabular}{|c|c|c|c|c|c|c|c|c|c|c|c|c|c|c|c|c|c|c|c|}
\hline$B C-1$ & ACF & 068 & 67AHx & 196 & 0.5 & $\mathbf{L}$ & $\mathbf{N}$ & 0.06 & - & L & 200 & 1 & $\mathrm{~N}$ & $\mathbf{N}$ & L & 7 & 20 & $\mathbf{N}$ & $\mathbf{N}$ \\
\hline 2 & & 091 & & 197 & 1.5 & 1000 & $\mathbf{N}$ & .30 & - & 10 & 300 & 1 & $\mathbf{N}$ & $\mathbf{N}$ & $\mathbf{N}$ & 20 & 30 & $\mathrm{~N}$ & $\mathrm{~N}$ \\
\hline
\end{tabular}

Long Creek area (sample localities shown in fig. 9)

\begin{tabular}{|c|c|c|c|c|c|c|c|c|c|c|c|c|c|c|c|c|c|c|}
\hline & & & $\mathrm{Hx}$ & & & & & & & & & & & & & & & \\
\hline 1 & ACF & 096 & $218-1$ & 100 & $\mathbf{N}$ & $\mathrm{L}$ & 6.8 & $-\infty$ & 10 & 300 & $\mathbf{N}$ & 100 & $\mathbf{N}$ & 20 & 7 & 15,000 & $\mathrm{~N}$ & $\mathrm{~N}$ \\
\hline 2 & & 097 & -2 & 50 & $\mathrm{~N}$ & $\mathbf{N}$ & 1.2 & $-\infty$ & L & 1500 & $\mathrm{~N}$ & 100 & $\mathbf{N}$ & 70 & 15 & 20,000 & 50 & $\mathrm{~N}$ \\
\hline 3 & & 098 & -3 & 50 & $\mathrm{~N}$ & L & 8.0 & - & L & 2000 & $\mathbf{N}$ & 100 & $\mathbf{N}$ & 20 & 20 & 10,000 & 20 & $\mathrm{~N}$ \\
\hline 4 & & 099 & -4 & 30 & 200 & $\mathrm{~N}$ & 1.3 & $-\infty$ & $\mathbf{L}$ & 150 & $\mathrm{~N}$ & 100 & $\mathbf{N}$ & 150 & 20 & 5000 & $\mathrm{~N}$ & N \\
\hline 5 & & 061 & 169 & 0.7 & $\mathrm{~N}$ & $\mathbf{N}$ & $\mathbf{N}$ & $-\infty$ & $\mathbf{L}$ & 1000 & 1 & $\mathbf{N}$ & $\mathbf{N}$ & 5 & $\mathrm{~L}$ & 50 & $\mathbf{N}$ & 15 \\
\hline 6 & & 060 & 168 & 150 & $\mathbf{L}$ & $\mathrm{N}$ & 0.2 & - & 10 & 2000 & $\mathrm{~L}$ & 50 & 30 & 100 & 10 & $>20,000$ & 30 & $\mathrm{~N}$ \\
\hline 7 & & 062 & 170 & 1.5 & $\mathrm{~N}$ & $\mathbf{N}$ & .1 & - & $\mathbf{L}$ & 200 & $\mathbf{N}$ & $\mathrm{N}$ & $\mathbf{N}$ & 30 & 1000 & 100 & $\mathbf{N}$ & $\mathrm{N}$ \\
\hline 8 & $\mathrm{ACE}$ & 613 & 219 & .5 & $\mathrm{~N}$ & $\mathrm{~N}$ & $\mathrm{~N}$ & & 15 & 300 & $\mathrm{~L}$ & $\mathbf{N}$ & $\mathbf{N}$ & 70 & 1000 & 20 & $<50$ & $\mathrm{~N}$ \\
\hline 9 & $\mathrm{ACF}$ & 095 & 216 & 2 & $\mathbf{N}$ & $\mathbf{N}$ & .06 & $-\pi$ & L & 150 & $\overline{\mathbf{N}}$ & $\mathrm{N}$ & N & 15 & 10 & 2000 & N & $\mathbf{N}$ \\
\hline Limits & of de & eterm & & .5 & 200 & 10 & .02 & .05 & 10 & 5 & 1 & 10 & 20 & 5 & 5 & 5 & 20 & 5 \\
\hline
\end{tabular}

$\frac{1 /}{2}$ Atomic absorption.

2/ Fire assay or fire assay-atomic absorption.

$\underline{3}$ / Specific instrumental or chemical method.

Location Sample No. and description

Golden Zone area:

1 - . - . - Composite of random chips collected at about 3.0 -foot intervals over 150 feet in Golden Zone opencut.

2... . 15.0-foot chip sample of veinlike breccia zone, abundant arsenopyrite and quartz,

3 (Golden Zone locally abundant scorodite and copper stain.

mine) - - - Mill feed; crushed ore from 1942 operations in mill hopper, Golden Zone mill.

4 (Golden Zone

mine) - - - Coarse tailings, Golden Zone mill.

5 (U.S. Bureau

of Mines

$\mathrm{DH}-1$ ) - - Average (approximate geometric mean) of 18 composite sludge samples from $\mathrm{DH}-1$. Maximum gold content in any sample, 6.3 ppm. Molybdenum, detected in all samples, was determined quantitatively to range from 6 to $43 \mathrm{ppm}$. Samples furnished by U.S. Bureau of Mines.
Location Sample No. and description

Golden Zone area-Continued

$6 \ldots$..... Grab sample of arsenopyrite-quartz ore, Little vein. Abundant scorodite.

7 - . - 7A. East vein: Grab sample of ar senopyriterich vein material.

7B. East vein: Grab sample of galena-sphalerite-arsenopyrite vein material.

(See Mulligan and others (1967) for analyses of channel samples of East vein.)

Blind Creek area:

BC-1 - . - Composite sample of quartz and 1imonitic quartz. Sample consists of random chips picked up on traverse of several hundred feet along course of vein.

BC-2 - - 2.0-foot chip sample of pyritic-quartz $v$ e in on wall of main quartz vein. 
Farley, Jr., R. H. Heidel, and E. E. Martinez, and are reported in the symbols: N, not detected; L, detected but below limit of determination; ---, $\mathrm{Mg}, \mathrm{Ca}, \mathrm{Ti}$, which are given in percent. Gold analyses by atomic absorption fire assay-atomic absorption are by J. E. Troxel and Claude Huffman, Jr]

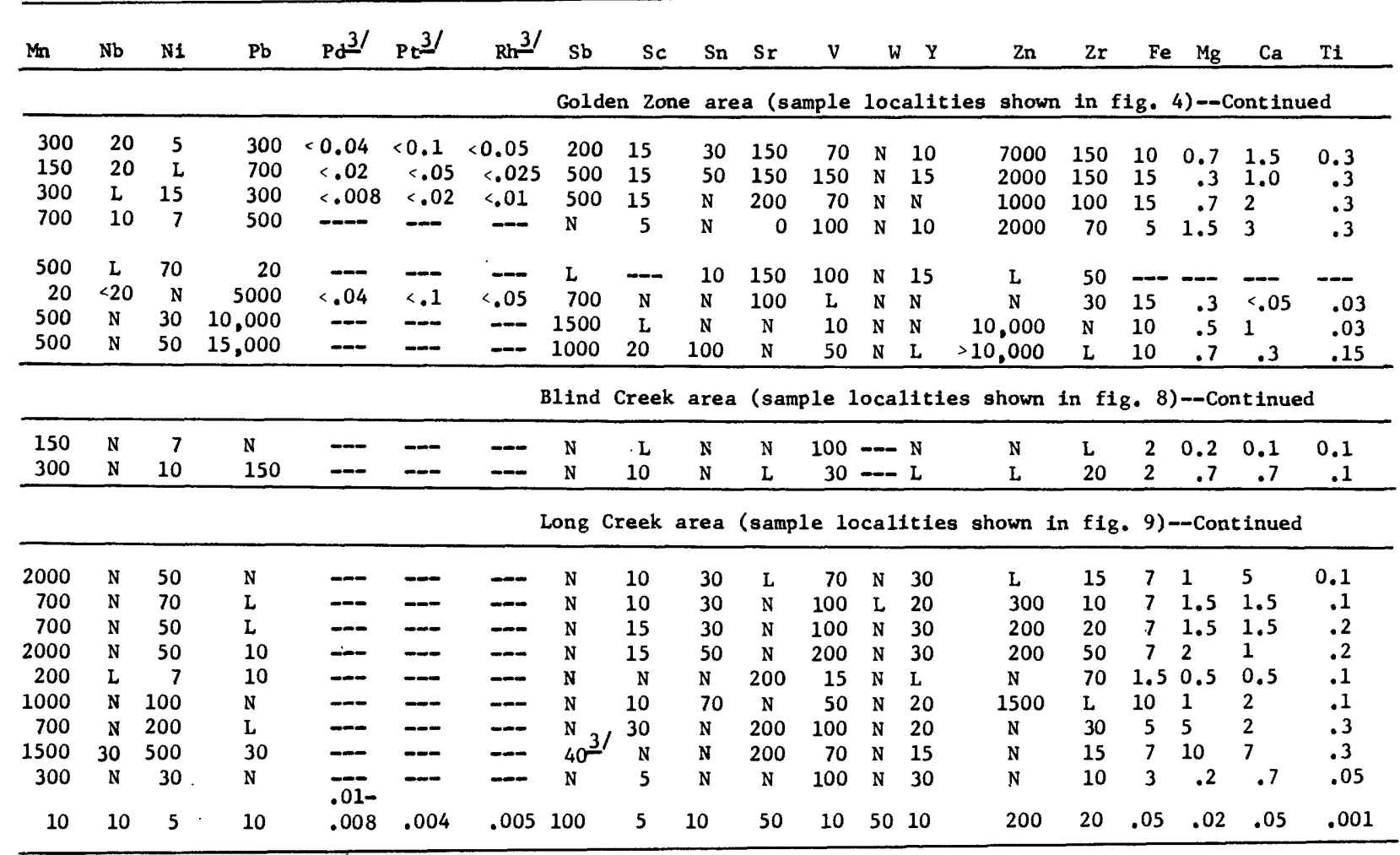

Location Sample No. and description

Long Creek area:

$1 \ldots . .-2.0$ - foot chip across strongly miner a lized layer in hornfelsed argillite. Layer strikes N. $82^{\circ}$ W., dips $52^{\circ} \mathrm{NE}$, and can be traced for about 100 feet.

2... - . 10.0-foot chip across massive chalcopyrite and pyrrhotite. Sulfide-rich zone trends N. $10^{\circ} \mathrm{W}$. , and probably dips to the east. Material from this same pit reported by Ross (1933) assayed $0.22 \mathrm{oz}$ per ton $\mathrm{Au}, 4.9 \mathrm{oz}$ per ton $\mathrm{Ag}$ and 7.34 percent $\mathrm{Cu}$.

3 - . . . - Random pieces of sulfide-rich material, same trend as sample 2 .

4 - . . - Composite of sulfide-bearing chips; main sulfide-bearing zone trends about $\mathrm{N} .80^{\circ} \mathrm{E}$.

5 - . . . - Grab sample of quartz porphyry cut by $1 / 4$ inch quartz veinlets on 2 -inch to 2 -foot spacing. Veinlets on several fracture sets including: N. $30^{\circ}$ W., dipping $65^{\circ}$ NE.; N. $25^{\circ}$ E., dipping $52^{\circ} \mathrm{NW}$.; and N. $85^{\circ}$ E., dipping $44^{\circ} \mathrm{NW}$. Sparse molybdenite, chalcopyrite, and pyrite in quartz veinlets.
Location Sample No. and description

Long Creek area-Continued

6 . . . . Grab sample of sacked orc.

7 - . . . Composite grab sample of chips collected at four corners of outcrop area in finegrained tuff and volcanic breccia which has very fine disseminated chalcopyrite in altered breccia fragments.

$8 \ldots \ldots$. . . Composite grab sample of chips collected on outcrop of green volcanic conglomerate. Green stain probably caused by chromium or nickel (see spectrographic analyses).

9 -...- Grab sample of copper-stained gossan, sheared limestone host rock. 
[Analyses, except of gold, are semiquantitative spectrographic by D. J. Grimes, $0.15,0.2,0.3,0.5,0.7,1.0,1.5$, and so on, or by the following symbols: looked for. Results are given in parts per million, except for $\mathrm{Fe}, \mathrm{Mg}, \mathrm{Ca}$, A. L. Meier, R. L. Miller, and T. A. Roemer. Sample localities are shown in

\begin{tabular}{|c|c|c|c|c|c|c|c|c|c|c|c|c|c|c|c|c|}
\hline $\begin{array}{c}\text { Sample } \\
\text { No. }\end{array}$ & & $\begin{array}{l}a b . \\
0 . \\
\end{array}$ & $\begin{array}{r}\text { Fie } \\
\text { No } \\
\end{array}$ & & $\mathrm{Ag}$ & As & $\mathrm{Au}$ & B & $\mathrm{Ba}$ & $\mathrm{Be}$ & Bi & $\mathrm{Cd}$ & Co & $\mathrm{Cr}$ & $\mathrm{Cu}$ & La \\
\hline 1 & ACK & 006 & $67 \mathrm{ACx}$ & 257 & $\mathbf{N}$ & $\mathrm{N}$ & $\mathrm{N}$ & 70 & 1500 & 1 & $\mathrm{~N}$ & $\mathrm{~N}$ & 15 & 300 & 70 & $\mathrm{~N}$ \\
\hline 2 & & 005 & & 256 & $\mathrm{~N}$ & $\mathbf{N}$ & $\mathrm{N}$ & 70 & 1000 & 1 & $\mathrm{~N}$ & $\mathrm{~N}$ & 15 & 200 & 70 & $\mathrm{~N}$ \\
\hline 3 & & 007 & & 258 & 0.5 & $\mathrm{~N}$ & $\mathrm{~N}$ & 100 & 1500 & 1 & $\mathrm{~N}$ & $\mathrm{~N}$ & 15 & 200 & 70 & $\mathrm{~N}$ \\
\hline 4 & & 004 & & 254 & $\mathbf{N}$ & $\mathrm{N}$ & $\mathrm{N}$ & 50 & 1000 & L & $\mathrm{N}$ & $\mathrm{N}$ & 10 & 70 & 50 & L \\
\hline 5 & & 003 & & 253 & $\mathrm{~N}$ & $\mathrm{~N}$ & $\mathrm{~N}$ & 70 & 1500 & 1 & $\mathrm{~N}$ & $\mathrm{~N}$ & 15 & 300 & 70 & $\mathrm{~N}$ \\
\hline 6 & & 008 & & 259 & $\mathbf{N}$ & $\mathrm{N}$ & $\mathrm{N}$ & 70 & 1000 & 1 & $\mathrm{~N}$ & $N$ & 20 & 200 & 70 & L \\
\hline 7 & & 002 & & 176 & N & $\mathrm{N}$ & $\mathbf{N}$ & 50 & 700 & $\mathrm{~L}$ & $\mathrm{~N}$ & $\mathrm{~N}$ & 15 & 150 & 70 & $\mathrm{~N}$ \\
\hline 8 & $\mathrm{ACE}$ & 649 & & 169 & $\mathrm{~N}$ & $\mathrm{~N}$ & 0.4 & 30 & 700 & 1 & $\mathrm{~N}$ & $\mathrm{~N}$ & 20 & 200 & 70 & $\mathbf{N}$ \\
\hline 9 & & 650 & & 173 & $\mathrm{~N}$ & $\mathrm{~N}$ & .04 & 50 & 1000 & L & $\mathrm{N}$ & $\mathrm{N}$ & 15 & 150 & 50 & 20 \\
\hline 10 & & 651 & & 88 & N & $\mathrm{N}$ & $\mathrm{N}$ & 70 & 1000 & 1 & $\mathrm{~N}$ & $\mathrm{~N}$ & 20 & 150 & 70 & $\mathrm{~N}$ \\
\hline 11 & $\mathrm{ACF}$ & 104 & 67AHX & 31 & 2 & 1500 & N & 70 & 700 & $\mathrm{~N}$ & $\mathrm{~N}$ & $\mathbf{N}$ & 20 & 300 & 100 & 30 \\
\hline 12 & & 103 & & 30 & 1.5 & 5000 & $\mathrm{~N}$ & 70 & 500 & $\mathrm{~N}$ & $\mathrm{~N}$ & $\mathrm{~N}$ & 30 & 1500 & 300 & $\mathrm{~N}$ \\
\hline $12 a$ & ACE & 646 & & $39 a$ & $\mathrm{~N}$ & $\mathrm{~N}$ & $\mathrm{~N}$ & 100 & 1000 & $\mathrm{~L}$ & $\mathrm{~N}$ & $\mathrm{~N}$ & 15 & 200 & 30 & $\mathrm{~N}$ \\
\hline $12 a$ & & 647 & & $39 \mathrm{~b}$ & $\mathrm{~N}$ & $\mathrm{~N}$ & .02 & 100 & 1000 & 1 & $\mathrm{~N}$ & $\mathrm{~N}$ & 15 & 150 & 50 & $\mathrm{~N}$ \\
\hline $12 a$ & & 648 & & $39 \mathrm{p}$ & $L$ & $\mathrm{~N}$ & $\mathbf{N}$ & 70 & 1000 & L & $\mathbf{N}$ & $\mathrm{N}$ & 20 & 2000 & 30 & $\mathrm{~N}$ \\
\hline 13 & $\mathrm{ACF}$ & 069 & 67ACx & 64 & 3 & 3000 & .04 & 100 & 300 & 1 & $\mathbf{N}$ & $\mathrm{N}$ & 20 & 300 & 200 & $\mathrm{~N}$ \\
\hline 14 & $\mathrm{ACE}$ & 609 & $\mathrm{Hx}$ & 98 & $\mathrm{~N}$ & $\mathrm{~N}$ & $\mathrm{~N}$ & 70 & 1000 & 1 & $\mathrm{~N}$ & $\mathbf{N}$ & 20 & 150 & 100 & 20 \\
\hline 15 & & 610 & & 99 & .7 & 200 & $\mathrm{~N}$ & 70 & 1000 & 1.5 & $\mathbf{N}$ & $\mathbf{N}$ & 20 & 100 & 150 & 50 \\
\hline 16 & & 611 & & 100 & $\mathrm{~N}$ & $\mathrm{~N}$ & $\mathrm{~N}$ & 50 & 700 & 1 & N & $\mathrm{N}$ & 15 & 150 & 70 & 20 \\
\hline 17 & $\mathrm{ACF}$ & 032 & & 101 & $\mathrm{~N}$ & $\mathbf{N}$ & .04 & 50 & 500 & 1 & $\mathrm{~N}$ & $\mathrm{~N}$ & 7 & 150 & 30 & 20 \\
\hline 18 & $\mathrm{ACE}$ & 607 & 67AHX & 96 & N & N & $\mathrm{N}$ & 100 & 2000 & 1 & $\mathbf{N}$ & $\mathrm{N}$ & 30 & 150 & 100 & $\mathrm{~N}$ \\
\hline 19 & & 606 & & 95 & $\mathrm{~N}$ & $\mathrm{~N}$ & $\mathrm{~N}$ & 100 & 1000 & 1 & $\mathbf{N}$ & $\mathrm{N}$ & 20 & 150 & 100 & 30 \\
\hline 20 & & 605 & & 94 & $\mathrm{~N}$ & $\mathrm{~N}$ & $\mathrm{~N}$ & 100 & 3000 & 1.5 & $\mathrm{~N}$ & $\mathrm{~N}$ & 20 & 150 & 100 & 20 \\
\hline 21 & & 604 & & 93 & $\mathrm{~N}$ & $\mathrm{~N}$ & -- & 100 & 1000 & 1 & $\mathrm{~N}$ & $\mathrm{~N}$ & 20 & 150 & 70 & 20 \\
\hline 22 & & 603 & & 92 & $\mathrm{~N}$ & $\mathrm{~N}$ & $\mathbf{N}$ & 50 & 700 & 1 & $\mathrm{~N}$ & $\mathrm{~N}$ & 20 & 150 & 70 & $\mathrm{~N}$ \\
\hline 23 & & 602 & & 91 & $\mathrm{~N}$ & $\mathrm{~N}$ & $\mathrm{~N}$ & 50 & 700 & 1 & $\mathrm{~N}$ & $\mathrm{~N}$ & 20 & 150 & 100 & $\mathrm{~N}$ \\
\hline 24 & $\mathrm{ACF}$ & 028 & & 70 & 3 & 5000 & .7 & 100 & 700 & 1 & 10 & $\mathrm{~N}$ & 20 & 100 & 300 & 30 \\
\hline 25 & & 026 & & 68 & $\mathrm{~N}$ & $\mathbf{N}$ & .06 & 150 & 300 & 1 & $\mathbf{N}$ & $\mathrm{N}$ & 20 & 200 & 100 & $\mathrm{~N}$ \\
\hline 26 & & 027 & & 69 & $\mathrm{~N}$ & $\mathrm{~N}$ & $\mathrm{~N}$ & 100 & 300 & 1 & $\mathrm{~N}$ & $\mathrm{~N}$ & 20 & 300 & 150 & 20 \\
\hline 27 & & 029 & & 71 & $\mathrm{~N}$ & $\mathbf{N}$ & .04 & 50 & 2000 & 1 & $\mathrm{~N}$ & $\mathrm{~N}$ & 20 & 700 & 100 & $\mathrm{~N}$ \\
\hline 28 & & 031 & & 73 & $\mathbf{N}$ & $\mathrm{N}$ & $\mathrm{N}$ & 150 & 700 & 1 & $\mathrm{~N}$ & $\mathrm{~N}$ & 20 & 70 & 100 & 20 \\
\hline 29 & & 030 & & 72 & $\mathrm{~N}$ & $\mathbf{N}$ & .02 & 100 & 500 & 1 & $\mathrm{~N}$ & $\mathrm{~N}$ & 20 & 100 & 100 & 30 \\
\hline 30 & & 033 & & 103 & $\mathrm{~N}$ & $\mathrm{~N}$ & $\mathbf{N}$ & 100 & 500 & L & $\mathrm{N}$ & $\mathrm{N}$ & 20 & 70 & 70 & N \\
\hline 31 & & 082 & & 87 & $\mathrm{~N}$ & $\mathrm{~N}$ & $\mathbf{N}$ & 70 & 500 & $\mathrm{~L}$ & $\mathbf{N}$ & $\mathrm{N}$ & 20 & 70 & 70 & $L$ \\
\hline 32 & & 081 & & 86 & $\mathbf{N}$ & $\mathrm{N}$ & $\mathrm{N}$ & 50 & 700 & $\mathrm{~N}$ & $\mathrm{~N}$ & $\mathrm{~N}$ & 20 & 300 & 70 & $\mathrm{~N}$ \\
\hline
\end{tabular}


samples, upper Chulitna district

E. E. Martinez, and Arnold Farley, Jr., and are reported in the series 0.1 , $\mathrm{N}$, not detected; L, detected but below limit of determination; ---, not Ti, which are given in percent. Gold analyses are by atomic absorption by figure 10]

$\begin{array}{llllllllllllllllll}\mathrm{Mo} & \mathrm{Mn} & \mathrm{Nb} & \mathrm{Ni} & \mathrm{Pb} & \mathrm{Sb} & \mathrm{Sc} & \mathrm{Sn} & \mathrm{Sr} & \mathrm{V} & \mathrm{W} & \mathrm{Y} & \mathrm{Zn} & \mathrm{Zr} & \mathrm{Fe} & \mathrm{Mg} & \mathrm{Ca} & \mathrm{Ti}\end{array}$

$\begin{array}{rrrrrrrrrrrrrrrrrr}\mathrm{N} & 700 & \mathrm{~L} & 70 & 15 & \mathrm{~N} & 20 & \mathrm{~N} & 100 & 150 \mathrm{~N} & 20 & \mathrm{~L} & 150 & 5 & 1.5 & 0.7 & 0.5 \\ \mathrm{~N} & 500 & \mathrm{~L} & 100 & 15 & \mathrm{~N} & 15 & \mathrm{~N} & 150 & 150 & \mathrm{~N} & 15 & \mathrm{~L} & 100 & 5 & 1 & .3 & .5 \\ \mathrm{~N} & 700 & \mathrm{~L} & 70 & 20 & \mathrm{~N} & 15 & \mathrm{~N} & 150 & 100 \mathrm{~N} & 20 & \mathrm{~L} & 150 & 7 & 1.5 & .5 & .5 \\ \mathrm{~N} & 700 & \mathrm{~L} & 30 & 15 & \mathrm{~N} & 15 & \mathrm{~N} & 70 & 70 & \mathrm{~N} & 15 & \mathrm{~L} & 150 & 3 & .7 & 1.5 & .5 \\ \mathrm{~N} & 500 & \mathrm{~L} & 70 & 15 & \mathrm{~N} & 20 & \mathrm{~N} & 100 & 150 \mathrm{~N} & 20 & \mathrm{~L} & 150 & 5 & 1.5 & .7 & .5\end{array}$

$\begin{array}{rrrrrrrrrrrrrrrrr}\mathrm{N} & 700 & \mathrm{~L} & 100 & 15 & \mathrm{~N} & 15 & \mathrm{~N} & 100 & 100 \mathrm{~N} & 15 & \mathrm{~L} & 150 & 5 & 1.5 & .5 & .5 \\ \mathrm{~N} & 700 & \mathrm{~L} & 50 & 15 & \mathrm{~N} & 10 & \mathrm{~N} & 70 & 70 \mathrm{~N} & 15 & \mathrm{~N} & 100 & 3 & .7 & .2 & .3 \\ \mathrm{~N} & 700 \mathrm{~L} & 70 & 10 & \mathrm{~N} & 15 & \mathrm{~N} & 100 & 150 \mathrm{~N} & 15 & \mathrm{~L} & 150 & 5 & 1.5 & .5 & .3 \\ \mathrm{~N} & 700 & \mathrm{~L} & 50 & 15 & \mathrm{~N} & 15 & \mathrm{~N} & 100 & 100 \mathrm{~N} & 20 & \mathrm{~L} & 150 & 3 & 1 & .3 & .5 \\ \mathrm{~N} & 700 \mathrm{~L} & 30 & 20 & \mathrm{~N} & 15 & \mathrm{~N} & 100 & 150 & \mathrm{~N} & 20 & \mathrm{~N} & 100 & 5 & 1 & .5 & .5\end{array}$

$\begin{array}{lllllll}\text { N } 5000 & \text { L } & 70 & 30 & \text { N } & 20 & \text { N }\end{array}$

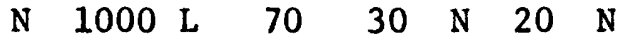

$\begin{array}{lllllllllll}\mathrm{N} & 1000 & \mathrm{~L} & 100 & 10 & \mathrm{~N} & 10 & \mathrm{~N}\end{array}$

N $1000 \mathrm{~L} \quad 70 \quad 10 \mathrm{~N} \quad 10 \mathrm{~N}$

$152000 \mathrm{~L} \quad 20020 \mathrm{~N} \quad 10 \mathrm{~N}$

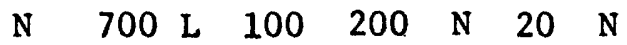

N $\quad \begin{array}{lllllll}700 & \mathrm{~L} & 70 & 30 & \mathrm{~N} & 15 & \mathrm{~N}\end{array}$

N $1000 \mathrm{~L} \quad 70 \quad 70 \quad \mathrm{~N} \quad 15 \mathrm{~N}$

$\begin{array}{lllllllllll}\mathrm{N} & 700 & \mathrm{~L} & 50 & 20 & \mathrm{~N} & 15 & \mathrm{~N}\end{array}$

$\begin{array}{lllllll}N & 700 \mathrm{~L} & 30 & 15 & \mathrm{~N} & 15 & \mathrm{~N}\end{array}$

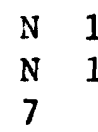

$\begin{array}{rrlrllll}\mathrm{N} & 1000 & \mathrm{~L} & 70 & 15 & \mathrm{~N} & 15 & \mathrm{~N} \\ \mathrm{~N} & 1000 & \mathrm{~L} & 70 & 30 & \mathrm{~N} & 15 & \mathrm{~N} \\ 7 & 700 & \mathrm{~L} & 100 & 15 & \mathrm{~N} & 15 & \mathrm{~N} \\ \mathrm{~N} & 700 & \mathrm{~L} & 70 & 20 & \mathrm{~N} & 15 & \mathrm{~N} \\ \mathrm{~N} & 700 & \mathrm{~L} & 50 & 20 & \mathrm{~N} & 15 & \mathrm{~N} \\ & & & & & & & \\ \mathrm{~N} & 700 & \mathrm{~L} & 70 & 20 & \mathrm{~N} & 20 & \mathrm{~N} \\ \mathrm{~N} & 700 & \mathrm{~L} & 50 & 70 & \mathrm{~N} & 15 & \mathrm{~N} \\ \mathrm{~N} & 700 & \mathrm{~L} & 100 & 10 & \mathrm{~N} & 20 & \mathrm{~N} \\ \mathrm{~N} & 700 & \mathrm{~L} & 100 & 20 & \mathrm{~N} & 20 & \mathrm{~N}\end{array}$

$\begin{array}{rrlrllll}\mathrm{N} & 1000 & \mathrm{~L} & 70 & 15 & \mathrm{~N} & 15 & \mathrm{~N} \\ \mathrm{~N} & 1000 & \mathrm{~L} & 70 & 30 & \mathrm{~N} & 15 & \mathrm{~N} \\ 7 & 700 & \mathrm{~L} & 100 & 15 & \mathrm{~N} & 15 & \mathrm{~N} \\ \mathrm{~N} & 700 & \mathrm{~L} & 70 & 20 & \mathrm{~N} & 15 & \mathrm{~N} \\ \mathrm{~N} & 700 & \mathrm{~L} & 50 & 20 & \mathrm{~N} & 15 & \mathrm{~N} \\ & & & & & & & \\ \mathrm{~N} & 700 & \mathrm{~L} & 70 & 20 & \mathrm{~N} & 20 & \mathrm{~N} \\ \mathrm{~N} & 700 & \mathrm{~L} & 50 & 70 & \mathrm{~N} & 15 & \mathrm{~N} \\ \mathrm{~N} & 700 & \mathrm{~L} & 100 & 10 & \mathrm{~N} & 20 & \mathrm{~N} \\ \mathrm{~N} & 700 & \mathrm{~L} & 100 & 20 & \mathrm{~N} & 20 & \mathrm{~N}\end{array}$

$\begin{array}{rrlrllll}\mathrm{N} & 1000 & \mathrm{~L} & 70 & 15 & \mathrm{~N} & 15 & \mathrm{~N} \\ \mathrm{~N} & 1000 & \mathrm{~L} & 70 & 30 & \mathrm{~N} & 15 & \mathrm{~N} \\ 7 & 700 & \mathrm{~L} & 100 & 15 & \mathrm{~N} & 15 & \mathrm{~N} \\ \mathrm{~N} & 700 & \mathrm{~L} & 70 & 20 & \mathrm{~N} & 15 & \mathrm{~N} \\ \mathrm{~N} & 700 & \mathrm{~L} & 50 & 20 & \mathrm{~N} & 15 & \mathrm{~N} \\ & & & & & & & \\ \mathrm{~N} & 700 & \mathrm{~L} & 70 & 20 & \mathrm{~N} & 20 & \mathrm{~N} \\ \mathrm{~N} & 700 & \mathrm{~L} & 50 & 70 & \mathrm{~N} & 15 & \mathrm{~N} \\ \mathrm{~N} & 700 & \mathrm{~L} & 100 & 10 & \mathrm{~N} & 20 & \mathrm{~N} \\ \mathrm{~N} & 700 & \mathrm{~L} & 100 & 20 & \mathrm{~N} & 20 & \mathrm{~N}\end{array}$

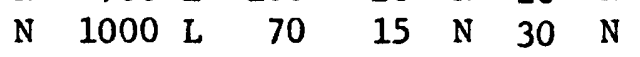

$150150 \mathrm{~N}$

$70100 \mathrm{~N}$

$150100 \mathrm{~N}$

$150150 \mathrm{~N}$

$15070 \mathrm{~N}$

$150100 \mathrm{~N}$

$150100 \mathrm{~N}$

$10 \quad$ L $\quad 150 \quad 15$

10 L $100 \quad 15$

15 L $50 \quad 3$

$.7 \quad .7 \quad .2$

15 L $50 \quad 5$

$\begin{array}{lll}1.5 & .7 & .5\end{array}$

$1.53 \quad .3$

$1.52 \quad .3$

$\begin{array}{llllll}15 & \mathrm{~L} & 70 & 5 & 1.53 & .3\end{array}$

$100200 \mathrm{~N}$

$150150 \mathrm{~N}$

$150150 \mathrm{~N}$

$\begin{array}{lll}20 & \mathrm{~N} & 1007\end{array}$

$\begin{array}{llll}15 & 200 \quad 70 & 5\end{array}$

$15 \mathrm{~N} \quad 705$

$15 \mathrm{~N} 705$

15 L 707

$\begin{array}{rrrrrrrr}\text { N } & 1000 & \text { L } & 30 & 20 & \text { N } & 20 & \text { N } \\ \text { N } & 1000 & \text { L } & 30 & 20 & \text { N } & 20 & \text { N } \\ \text { N } & 700 & \text { L } & 30 & 20 & \text { N } & 20 & \text { N } \\ \text { N } & 700 & \text { L } & 30 & 30 & \text { N } & 15 & \text { N } \\ \text { N } & 700 & \text { L } & 150 & 20 & \text { N } & 15 & \text { N }\end{array}$
$150150 \mathrm{~N}$

$100150 \mathrm{~N}$

$150150 \mathrm{~N}$

$150150 \mathrm{~N}$

$100100 \mathrm{~N}$
15

200

15

15

15

$\begin{array}{lrllll}\mathrm{N} & 100 & 7 & 1.5 & .5 & .5 \\ \mathrm{~N} & 100 & 7 & 1.5 & .3 & .7 \\ \mathrm{~N} & 70 & 7 & 1.5 & .7 & .5 \\ \mathrm{~N} & 100 & 7 & 1.5 & .7 & .5 \\ \mathrm{~L} & 70 & 5 & 1.5 & .3 & .3\end{array}$


Table 3.--Analyses of stream-sediment

\begin{tabular}{|c|c|c|c|c|c|c|c|c|c|c|c|c|c|c|c|c|}
\hline $\begin{array}{c}\text { Sample } \\
\text { No. }\end{array}$ & & ab. & $\begin{array}{c}\text { Fie } \\
\text { No }\end{array}$ & & $\mathrm{Ag}$ & As & $\mathrm{Au}$ & B & $\mathrm{Ba}$ & $\mathrm{Be}$ & $B i$ & $\mathrm{Cd}$ & Co & $\mathrm{Cr}$ & $\mathrm{Cu}$ & La \\
\hline 33 & ACF & 084 & 67 AHx & 89 & $\mathrm{~N}$ & $\mathrm{~N}$ & $\mathrm{~N}$ & 70 & 700 & L & $\mathrm{N}$ & N & 20 & 150 & 70 & $\mathrm{~N}$ \\
\hline 34 & & 085 & & 90 & L & $\mathrm{N}$ & $\mathrm{N}$ & 50 & 500 & L & $\mathbf{N}$ & $\mathrm{N}$ & 15 & 150 & 50 & $\mathrm{~N}$ \\
\hline 35 & & 083 & & 88 & $\mathrm{~N}$ & $\mathrm{~N}$ & $\mathrm{~N}$ & 30 & 500 & L & $\mathrm{N}$ & $\mathrm{N}$ & 20 & 300 & 50 & $\mathrm{~N}$ \\
\hline 36 & & 055 & & 115 & $\mathrm{~N}$ & $\mathrm{~N}$ & .02 & 70 & 300 & L & $\mathrm{N}$ & $\mathrm{N}$ & 15 & 150 & 70 & $\mathrm{~N}$ \\
\hline 37 & & 035 & & 114 & N & $\mathrm{N}$ & $\mathrm{N}$ & 50 & 500 & L & $\mathrm{N}$ & $\mathrm{N}$ & 20 & 150 & 70 & $\mathrm{~N}$ \\
\hline 38 & - & 034 & & 113 & $\mathrm{~N}$ & $\mathrm{~N}$ & .02 & 50 & 700 & L & $\mathrm{N}$ & $\mathrm{N}$ & 15 & 100 & 70 & L \\
\hline 40 & & 070 & & 75 & $\mathrm{~N}$ & $\mathrm{~N}$ & $\mathrm{~N}$ & 70 & 700 & L & $\mathrm{N}$ & $\mathrm{N}$ & 20 & 100 & 70 & $\mathrm{~N}$ \\
\hline 41 & & 072 & & 77 & $\mathrm{~N}$ & $\mathrm{~N}$ & $\mathrm{~N}$ & 30 & 500 & L & $\mathrm{N}$ & $\mathrm{N}$ & 15 & 150 & 100 & $\mathrm{~N}$ \\
\hline 42 & & 071 & & 76 & $\mathrm{~N}$ & $\mathrm{~N}$ & $\mathrm{~N}$ & 70 & 700 & L & $\mathrm{N}$ & $\mathrm{N}$ & 20 & 300 & 100 & $\mathrm{~N}$ \\
\hline & & & & & & & & & & L & & & & & & \\
\hline 43 & & 073 & & 78 & L & L & $\mathrm{N}$ & 30 & 500 & L & $\mathrm{N}$ & $\mathrm{N}$ & 15 & 150 & 100 & $\mathrm{~N}$ \\
\hline 44 & & 074 & & 79 & 7 & $\mathrm{~N}$ & $\mathrm{~N}$ & 70 & 300 & L & $\mathrm{N}$ & $\mathrm{N}$ & 30 & 2000 & 70 & $\mathrm{~N}$ \\
\hline 45 & & 075 & & 80 & $\mathrm{~N}$ & $\mathrm{~N}$ & $\mathrm{~N}$ & 70 & 700 & L & $\mathrm{N}$ & $\mathrm{N}$ & 20 & 200 & 70 & $\mathrm{~N}$ \\
\hline 46 & & 077 & & 82 & $\mathrm{~N}$ & $N$ & $\mathrm{~N}$ & 70 & 700 & L & $\mathrm{N}$ & $\mathrm{N}$ & 20 & 200 & 70 & $\mathrm{~N}$ \\
\hline 47 & & 076 & & 81 & $\mathrm{~N}$ & N & $\mathrm{N}$ & 70 & 700 & L & $\mathrm{N}$ & $\mathrm{N}$ & 20 & 500 & 100 & $\mathrm{~N}$ \\
\hline 48 & & 078 & & 83 & $\mathrm{~N}$ & $\mathrm{~N}$ & $\mathrm{~N}$ & 70 & 700 & L & $\mathrm{N}$ & $\mathrm{N}$ & 20 & 1000 & 100 & N \\
\hline 49 & & 079 & & 84 & $\mathrm{~N}$ & $\mathrm{~N}$ & $\mathrm{~N}$ & 70 & 700 & L & N & $\mathrm{N}$ & 20 & 150 & 70 & N \\
\hline & & & & & .5 & 200 & .02 & 10 & 5 & 1 & 10 & 20 & 5 & 5 & 5 & 20 \\
\hline
\end{tabular}


samples, upper Chulitna district--Continued

\begin{tabular}{|c|c|c|c|c|c|c|c|c|c|c|c|c|c|c|c|c|c|}
\hline Mo & Mn & $\mathrm{Nb}$ & $\mathrm{Ni}$ & $\mathrm{Pb}$ & $\mathrm{Sb}$ & Sc & $\mathrm{Sn}$ & $\mathrm{Sr}$ & $\mathrm{V}$ & $W$ & $\mathrm{Y}$ & $\mathrm{Zn}$ & $\mathrm{Zr}$ & $\mathrm{Fe}$ & Mg & $\mathrm{Ca}$ & $\mathrm{Ti}$ \\
\hline $\mathrm{N}$ & 1500 & L & 50 & 20 & $\mathrm{~N}$ & 15 & $\mathbf{N}$ & 100 & 100 & $\mathbf{N}$ & 15 & L & 100 & 5 & 2 & .3 & .7 \\
\hline $\mathrm{N}$ & 700 & $\mathrm{~L}$ & 50 & 70 & $\mathrm{~N}$ & 10 & $\mathrm{~N}$ & 50 & 100 & $\mathrm{~N}$ & 15 & L & 70 & 5 & 1 & .15 & .3 \\
\hline $\mathrm{N}$ & 700 & L & 100 & 15 & $\mathrm{~N}$ & 15 & $\mathrm{~N}$ & 70 & 100 & $\mathrm{~N}$ & 15 & $\mathrm{~L}$ & 70 & 5 & 1.5 & .2 & .3 \\
\hline $\mathrm{N}$ & 700 & $L$ & 50 & 15 & $\mathrm{~N}$ & 15 & $\mathrm{~N}$ & 100 & 100 & $\mathrm{~N}$ & 15 & $N$ & 100 & 3 & 1 & .5 & .5 \\
\hline $\mathrm{N}$ & 700 & $\mathrm{~L}$ & 50 & 15 & $\mathrm{~N}$ & 15 & $\mathrm{~N}$ & 100 & 100 & $\mathrm{~N}$ & 15 & $\mathrm{~N}$ & 70 & 3 & 1 & 2 & .5 \\
\hline $\mathrm{N}$ & 700 & L & 30 & 15 & $\mathrm{~N}$ & 30 & $\mathrm{~N}$ & 300 & 100 & $\mathrm{~N}$ & 15 & $\mathrm{~N}$ & 70 & 5 & 1 & .5 & .5 \\
\hline $\mathrm{N}$ & 700 & L & 50 & 10 & $\mathrm{~N}$ & 15 & $\mathrm{~N}$ & 150 & 100 & $\mathrm{~N}$ & 15 & $\mathrm{~N}$ & 100 & 5 & 1.5 & 1 & .5 \\
\hline $\mathrm{N}$ & 700 & L & 70 & 15 & $\mathbb{N}$ & 15 & $\mathbf{N}$ & 200 & 150 & $\mathrm{~N}$ & 15 & $\mathbf{N}$ & 150 & 5 & 1.5 & 1.5 & .5 \\
\hline $\mathrm{N}$ & 700 & L & 100 & 20 & $\mathrm{~N}$ & 15 & $\mathrm{~N}$ & 70 & 150 & $\mathrm{~N}$ & 20 & $\mathrm{~N}$ & 150 & 7 & 1.5 & .5 & .7 \\
\hline $\mathrm{N}$ & 700 & L & 70 & 20 & $\mathrm{~N}$ & 15 & $\mathrm{~N}$ & 50 & 100 & $\mathrm{~N}$ & 15 & $\mathrm{~N}$ & 70 & 3 & 1 & .5 & .3 \\
\hline $\mathrm{N}$ & 1000 & L & 300 & 70 & $\mathrm{~N}$ & 15 & $\mathrm{~N}$ & $\mathrm{~L}$ & 100 & $\mathrm{~N}$ & 15 & L & 70 & 7 & 3 & .2 & .3 \\
\hline $\mathrm{N}$ & 700 & L & 100 & 20 & $\mathrm{~N}$ & 15 & $\mathrm{~N}$ & 150 & 100 & $\mathrm{~N}$ & 15 & $\mathrm{~N}$ & 100 & 5 & 1.5 & 1.5 & .3 \\
\hline $\mathrm{N}$ & 700 & $\mathrm{~L}$ & 150 & 30 & $\mathrm{~N}$ & 15 & $\mathbf{N}$ & 200 & 100 & $\mathrm{~N}$ & 15 & $\mathrm{~N}$ & 100 & 5 & 2 & 1.5 & .5 \\
\hline $\mathrm{N}$ & 700 & L & 150 & 20 & $\mathrm{~N}$ & 15 & $\mathrm{~N}$ & 200 & 150 & $\mathbf{N}$ & 15 & $\mathrm{~N}$ & 100 & 7 & 2 & 1.5 & .5 \\
\hline $\mathrm{N}$ & 700 & L & 150 & 15 & $\mathrm{~N}$ & 15 & $\mathrm{~N}$ & 300 & 150 & $\mathrm{~N}$ & 15 & $\mathrm{~N}$ & 100 & 7 & 2 & 2 & .7 \\
\hline $\mathrm{N}$ & 1000 & L & 150 & 20 & $\mathrm{~N}$ & 20 & $\mathrm{~N}$ & 150 & 150 & $\mathrm{~N}$ & 15 & $\mathrm{~N}$ & 100 & 5 & .15 & .3 & .3 \\
\hline 5 & 10 & 10 & 2 & 10 & 100 & 5 & 10 & 50 & 10 & 50 & 10 & 200 & 20 & .05 & .02 & .05 & .001 \\
\hline
\end{tabular}

